\title{
ANTINUTRITIONAL FACTORS IN LEGUMES / \\ OF THE SONORAN DESERT
}

\author{
by \\ Kevin Arthur Thorn \\ /1
}

\author{
A Thesis Submitted to the Faculty of the \\ COMMITTEE ON AGRICULTURAL BIOCHEMISTRY AND NUTRITION (GRADUATE) \\ In Partial Fulfillment of the Requirements \\ For the Degree of \\ MASTER OF SCIENCE \\ In the Graduate College \\ THE UNIVERSITY OF ARIZONA
}




\section{STATEMENT BY AUTHOR}

This thesis has been submitted in partial fulfillment of requirements for an advanced degree at The University of Arizona and is deposited in the University Library to be made available to borrowers under rules of the library.

Brief quotations from this thesis are allowable without special permission, provided that accurate acknowledgement of source is made. Requests for permission for extended quotation from or reproduction of this manuscript in whole or in part may be granted by the copyright holder.

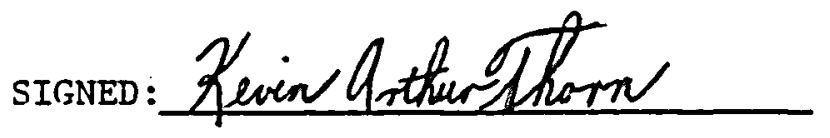

\section{APPROVAL BY THESIS DIRECTOR}

This thesis has been approved on the date shown below:
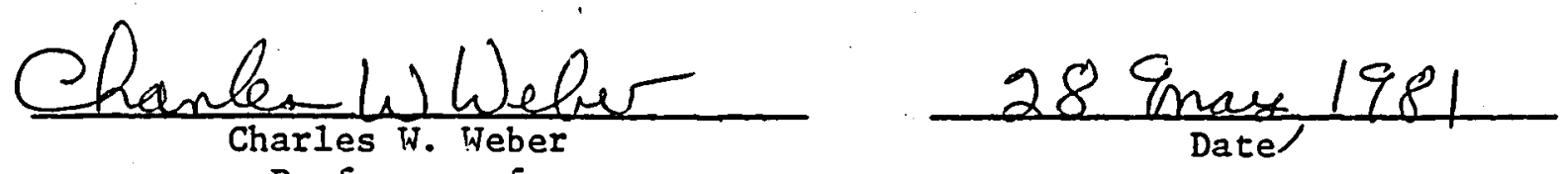

Nutrition and Food Science 
DEDICATION

To a leguminous future!

iii 


\section{ACKNOWLEDGEMENT}

I would like to thank Dr. Charles Weber, my advisor, and Dr. James Berry, for providing me the opportunity to undertake this project, and for their help in carrying it out. I would also like to thank Dr. Bobby L. Reid for serving on my comittee. I also owe a special thanks to Curt Henderson for his help and collaboration in the lectin and trypsin inhibitor work. The students and staff of Dr. Berry and Weber's research group made my time in the laboratory an enjoyable one.

The World Hunger Committee of the United Methodist Church provided the funding for this project. To the members of this committee, I am much indebted. 
TABLE OF CONTENTS

Page

LIST OF TABLES. . . . . . . . . . . . . . . . . . . . . vii

LIST OF FIGURES . . . . . . . . . . . . . . . . . . . . . . viii

ABSTRACT. . . . . . . . . . . . . . . . . . . . . . ix

CHAPTER

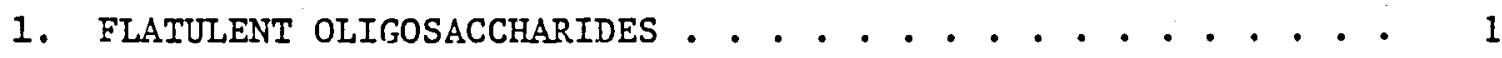

Literature Review. . . . . . . . . . . . . . 1

Elimination of Flatulence. . . . . . . . . . 5

Methods of Analysis. ............... 6

Methodology. . . . . . . . . . ... . . . . . 6

Sample Preparation . . . . . . . . . . . . . 7

Preparation of Standard Solution... . . . . . . 8

Chromatographic Analysis of Extracts . . . . . . . 9

Results and Discussion............... 10

2. TRYPSIN INHIBITORS . . . . . . . . . . . . . . 15

Literature Review. . . . . . . . . . . . . 15

Assay Methods. . . . . . . . . . . . 19

Methodology. . . . . . . . . . . . . . 20

Approach to Trypsin Inhibitor Analysis . . . . . 20

Preparation of Reagents. . . . . . . . . . 21

Assay Procedure. . . . . . . . . . . . . 22

Sample Calculation ............. . 24

Results and Discussion.............. . 28

3. LECTINS. . . . . . . . . . . . . . . . . 29

Literature Review. . . . . . . . . . . 29

Processing Effects................ 34

Assay Methods. . . . . . . . . . . . 35

Methodology. . . . . . . . . . . . . . . 36

Preparation of Samples............. 37

Preparation of Blood . . . . . . . . . . 37

Microliter Test. . . . . . . . . . . . . 38

Results and Discussion... . . . . . . . . . 39 
4. PHYTIC ACID. ................. . . 47

Literature Review. . . . . . . . . . . . . 47

Methods of Analysis. . . . . . . . . . . 51

Methodology. . . . . . . . . . . . . 52

Materials. . . . . . . . . . . . . 53

Phosphorus Determination ............ . 53

Testing of Procedure with Standards. . . . . . . . 54

Pre-testing of Procedure Using Original Protocol of

Harland and oberleas . . . . . . . . . . 57

Determination of Inorganic Phosphorus and Phytic

Acid in Bean Samples . . . . . . . . . . 59

Sample Calculation . . . . . . . . . . . 59

Results and Discussion . . . . . . . . . . . 60

5. CYANOGENIC GLYCOSIDES. .............. . 69

Iiterature Review. . . . . . . . . . . . . 69

Methodology. . . . . . . . . . . . . . . . 74

Testing Out of Procedure............ . 75

Analysis of Samples. . . . . . . . . . . 75

Results and Discussion............... 76

6. SUMMARY OF RESULTS . . . . . . . . . . . . . 78

APPENDIX A: CALCULATIONS FOR FLATULENT OLIGOSACCHARIDES • • 83

REFERENCES . . . . . . . . . . . . . . . 86 


\section{LIST OF TABLES}

Table

Page

1. Chromatographic Peak Areas of Oligosaccharides . . . . . 13

2. Oligosaccharide Contents of Bean Samples . . . . . . . . . 14

3. Trypsin Inhibitor Activities of Bean Samples . . . . . . . . 28

4. Titer Values for Hemagglutination of Pronase-Treated Rabbit Red Blod Cells by Lectin Extracts . . . . . . 42

5. Titer Values for Hemagglutination of Trypsin and Pronase Treated Bovine Red Blood Cells by Lectin Extracts. . . . . . . . . . . . 4 43

6. Titer Values for Hemagglutination of Pronase-Treated Hamster Red Blood Cells by Lectin Extracts . . . . . 44

7. Percent Reduction of Hemagglutinating Activity by Heat Treatment. . . . . . . . . . . . . 45

8. Dilutions of Lectin Extracts Corresponding to Titer Values . 46

9. Percent Recoveries for Inorganic Phosphorus. . . . . . . . 55

10. Percent Recoveries of Phytate from Phytate/Inorganic Phosphorus Standards . . . . . . . . . 56

11. Percent Recoveries of Inorganic Phosphorus and Phytate from Original Procedure of Harland . . . . . . . 58

12. Inorganic Phosphorus Analyses. . . . . . . . . . . . 62

13. Phytic Acid Analyses . . . . . . . . . . . . . 65

14. Inorganic Phosphorus and Phytic Acid Contents of Samples . . 68

15. Sumary of Antinutritional Factors . . . . . . . . . . . 81

16. Summary of Antinutritional Factors . . . . . . . . . . 82 


\section{LIST OF FIGURES}

Figures

Page

1. Peak Areas of Standards. . . . . . . . . . . . . 10

2. Response Factors of Standards. . . . . . . . . . . 10

3. Microtiter Test. . . . . . . . . . . . . . 38 
ABSTRACT

This study has analyzed ten samples of legumes indigenous to the Sonoran Desert for five antinutritional factors: flatulent oligosaccharides, trypsin inhibitors, lectins, phytic acid, and cyanogenic glycosides. The beans represented the following four species: Phaseolus acutifolius latifolius, Phaseolus vulgaris, Lysiloma watsonii, and Cercidium microphyllum. The raffinose and stachyose contents of the beans ranged from $0.00-3.57 \%$ and $0.00-5.45 \%$, respectively. The trypsin inhibitor activities ranged from 2.3 to $60.4 \mathrm{TIU} / \mathrm{mg}$; heat treatment decreased TI activity anywhere from 0-97\%. Phytic acid ranged from 0.48-1.02\%. No evidence of cyanogenic glycosides was found in any of the samples. The hemagglutinating activities of the sample extracts were assayed with pronase treated rabbit and hamster red blood cells, and trypsinated bovine red blood cells. All of the bean samples examined agglutinated all three blood types. The reduction of hemaglutinating activity upon heat treatment ranged from 0 to $100 \%$. 
CHAPTER 1

\section{FLATULENT OLIGOSACCHARIDES}

\section{- $\quad$ Literature Review}

Flatulence has been reviewed by Berk (1968), Rackis (1975), and Levitt and Bond (1980).

Murohy (1964) first demonstrated that the flatulence causing factor from cooked dry beans could be extracted with $60 \%$ ethanol, dialyzed through cellulose sausage casing, and then be solubilized in $85 \%$ ethanol. This suggested that the flatus producing substances were of low molecular weight. Steggerda (1968) showed that the gas producing fraction in soybeans resided in the low molecular weight fraction of the carbohydrate where the mono- and disaccharides as well as the oligosaccharides are found. The princtpal oligosaccharides found in soybeans are stachyose and rafinose. It is now accepted that the alpha galactosidic oligosaccharides, raffinose, stachyose, and verbascose, are responsible in part for flatus production following the ingestion of legumes. In addition, Olson (1979) has claimed that some as yet unidentified water insoluble components involving the food fiber fraction of legumes, which may constitute $15-25 \%$ of dry legumes, can be of as equal importance to flatus production as the oligosaccharides. Like the flatulent oligosaccharides, these unknown components cannot be hydrolyzed and absorbed in the upper digestive tract, and so pass on to the lower digestive tract where they are fermented by the intestinal microflora. The flatulent 
sugars and the unknown fraction can work together synergistically.

When raffinose, stachyose, and verbascose reach the colon, they are fermented by the colonic bacteria with the direct release of $\mathrm{H}_{2}$ and $\mathrm{CO}_{2}$. The organic acids produced from the fermentation process lower the $\mathrm{pH}$ and react with bicarbonate to produce further $\mathrm{CO}_{2}$. Although methane is sometimes reported to be a component of flatus, $\mathrm{CH}_{4}$ production in man doesn't appear to depend on the ingestion of nonabsorbed substances; the substrates necessary for $\mathrm{CH}_{4}$ production have not been clearly defined. Methane is produced solely by methanogenic bacteria in the colon. Only about $1 / 3$ of adult Americans have been found to possess sufficient numbers of $\mathrm{CH}_{4}$ - liberating bacteria to produce appreciable quantities of gas (Bond et al., 1971).

Some of the findings leading to the current understanding of flatus production are summarized here.

Gitzelman and Auricchio (1965) found no alpha-galactosidease activity in human intestinal mucosa.

Rutloff et al. (1967) found that no enzymatic hydrolysis of raffinose occurred in the intestinal mucosa of rats, pigs, and humans.

Studies by Taeufel et al. (1967) and Krause et al. (1968) on the absorption and degradation of oligosaccharides containing alpha-galactosyl groups showed that less than $1 \%$ of an administered dose was able to pass through the intestinal wall of man and animals.

In a series of detailed experiments with rats, Cristofaro et al. (1972) found that diets containing stachyose and verbascose exhibited the highest flatus activity. Carbon dioxide and hydrogen were the 
primary gases collected. Raffinose and lactose induced an insignificant increase in flatus.

Richards and Steggerda (1966) reported that $80 \%$ of the gas produced in surgically prepared intestinal segments of the dog, when incubated with a navy bean homogenate, occurred in the ileum and colon.

Based on studies of anaerobic cultures of the dog colon, Richards et al. (1958) concluded that Clostridium perfringens was primarily responsible for the production of flatus in the ileum and colon. This bacterium is normally present in the GI tract of man and animals. Rockland et al. (1969) published data to show that the growth of Clostridia is stimulated by a substrate containing beans. Carbon dioxide and hydrogen were the major gases formed.

Calloway et al. (1966) cultured dejecta from human ileal and colonic segments of the intestine vith stachyose. Large amounts of gas were produced; the dominant gases were $58-62 \% \mathrm{CO}_{2}$ and $28-36 \% \mathrm{H}_{2}$. Twelve percent $\mathrm{CH}_{4}$ was produced only with colon dejecta. These data suggested that intestinal flora contain an alpha-1,6-galactosidase.

That anaerobic cultures isolated from dog colon biopsies can metabolize raffinose and stachyose to produce high concentrations of $\mathrm{CO}_{2}$ and $\mathrm{H}_{2}$ was confirmed by Rackis et al. (1970). Glucose gave the most gas and at a rate greater than for either fructose or galactose. Gas production occurred at the slowest rate for raffinose and stachyose. Presumably, oligosaccharides break down to monosaccharides before the gas producing mechanism can occur.

When humans experience flatulence following a meal containing cooked dry beans, the peak passage of flatus occurs 4-6 hours after 
ingestion. The flatus is mainly due to increased amounts of $\mathrm{CO}_{2}$ and $\mathrm{H}_{2}$. In diets containing soy flour, the problem has been observed to manifest itself 8-10 hours after ingestion. Basal diets produce, on the average, $13 \mathrm{ml}$ of flatus/hour. On a navy bean diet, flatus volume increases to an average of $179 \mathrm{ml} / \mathrm{hr}$. Some volunteers produced less than $5 \mathrm{ml} / \mathrm{hr}$ on a test meal of navy beans and others nearly $500 \mathrm{ml}$ (Rackis, 1975).

Wagner et al. (1977) evaluated $\mathrm{H}_{2}$ production in the rat after ingestion of legume products as a predictive bioassay of their flatulence activity for man. Humans and rats were fed diets consisting of cooked California small white bean solids, $70 \%$ ethanol extracts of the cooked beans, oligosaccharide fractions of the $70 \%$ ethanol extracts, non protein nitrogen fractions of the $70 \%$ ethanol extracts, and combinations of the oligosaccharide and non protein nitrogen fraction of the ethanol extracts. Total flatus volume, $\mathrm{H}_{2}, \mathrm{CO}_{2}$, and $\mathrm{CH}_{4}$ volumes and breath $\mathrm{H}_{2}$ concentrations were measured for the interval 2.5 to 8.5 hours after ingestion with the human subjects. Rats were housed in metabolic chambers; $\mathrm{H}_{2}$ trapped in the chambers was measured 20 hours after ingestion of the meals. The corelation of rat $\mathrm{H}_{2}$ to human breath $\mathrm{H}_{2}$ measurements and flatus gas volumes were significant and positive except for a negative correlation with flatus methane volume. The authors suggested that measurement of $\mathrm{H}_{2}$ production in the rat has potential for a predictive bioassay for flatulence in man.

Kawamura (1967) reported the total oligosaccharide content of dejulled, defatted soybean meal to be $13.3 \%$. Sucrose, stachyose, and raffinose constituted $6.6,5.3$, and $1.4 \%$ respectively. Only a trace amount of verbascose was found. 
Hymowitz et al. (1972) determined the oligosaccharide contents of several varieties of soybeans. The range of means for sucrose, raffinose, and stachyose were found to be 5.06-6.78\%, $0.54-0.95 \%$, and $2.23-$ $3.05 \%$, respectively. Total sugar ranged from $8.30-10.11 \%$.

Cristofaro (1972) determined the oligosaccharide contents in several species of legumes, including chick peas, cow peas, field beans, and lentils. Rafinose ranged from $0.2-1.1 \%$, stachyose $1.2-4.8 \%$, and verbacose $0.5-4.0 \%$.

Elimination of Flatulence

Numerous papers dealing with the elimination of flatulence causing factors from food products have appeared in the literature.

Reynolds (1974) used an immobilized alpha-galactosidase continuous flow reactor to reduce the rafinose contents in beet sugar molasses.

Kim et al. (1973) removed approximately $70 \%$ of the raffinose and stachyose from soybeans by a combination of various treatments that involved $\mathrm{pH}$ adjustment, soaking, and germination.

Cristofaro et al. (1972) reported that germinating soybeans contain an alpha-galactosidase since raffinose and stachyose decreased rapidly during the first 3 days and disappeared after 5 days of germination.

Calloway et al. (1971), on the other hand, observed that soybean and mung bean sprouts retained most of the flatulence inducing activity of the intact seed when tested in humans.

In contrast again, Becker et al. (1974 found that autolysis of California small white beans, as measured by the disappearance of alphaoligosaccharides, significantly reduced rat $\mathrm{H}_{2}$ production. 
Gupta and Wagle (1980) reported that the levels of raffinose and stachyose in three varieties of beans decreased to the following percentages after 4 days of germination:

\begin{tabular}{|l|ll|ll|ll|}
\hline Oligosaccharide & $\underline{\underline{p}}$. mungoreous & $\underline{\underline{P}}$. mungo & \multicolumn{2}{c|}{$\underline{\underline{P}}$. aureus } \\
\hline Raffinose & 1.02 & $0.10 \%$ & 0.87 & $0.06 \%$ & 0.72 & $0.05 \%$ \\
Stachyose & 1.10 & $0.08 \%$ & 1.16 & $0.08 \%$ & 1.16 & $0.07 \%$ \\
\hline
\end{tabular}

Stern et al. (1977) have developed a fermented soybean product in which raffinose and stachyose are hydrolyzed and fermented during the process. A strain of Lactobacillus acidonhilus was used.

Methods of Analysis

There have been several approaches to the analysis of flatulence oligosaccharides in foodstuffs.

DeStefanis and Ponte (1968) used thin layer chromatography to analyze for the sugars.

Delente and Ladenburg (1972) silylated the oligosaccharides in soybean meal. The trimethylsilyl esters were then analyzed by gas chromatogradhy.

Gel filtration and carbon column chromatography have also been used (Technical Bulletin \#6506-1, Pharmacia Fine Chemicals).

Most recently, Black and Bagley (1977) have used high performance liquid chromatography to analyze soybeans for flatulent oligosaccharides.

\section{Yethodology}

The HPLC Method of Black and Bagley (1978) was used to analyze the bean samples for flatulence oligosaccharides. Raffinose was used as 
an internal standard. The one important deviation from the procedure was that hydrogen sulfide was used instead of oxalic acid to precipitate excess lead from the oligosaccharide extracts.

\section{Sample Preparation}

The beans were ground in a Wiley Mill through a no. 30 screen and defatted with hexane in a Goldfisch apparatus for ten hours. After drying, 1.0-1.5 gram samples were weighed out into $50 \mathrm{ml}$. plastic centrifuge tubes. The samples were extracted with $80 \% \mathrm{EtOH}$ in a water bath maintained at $79^{\circ} \mathrm{C}$. Four extractions, involving frequent stirring with a glass rod, were carried out according to the following protocol:

1st Extraction: $13 \mathrm{ml}$. EtOH, 30 minutes

2nd Extraction: $10 \mathrm{ml}$. EtOH, 30 minutes

3rd Extraction: $10 \mathrm{ml}$. EtOH, 30 minutes

4th Extraction: $13 \mathrm{ml}$. EtOH, 45 minutes

After each extraction, the tubes were centrifuged for 3 minutes at $2000 \mathrm{rpm}$. The supernatants were collected in $100 \mathrm{ml}$ beakers. The oligosaccharide extracts were then deproteinated with $2.5 \mathrm{ml}$ of $10 \%$ $\mathrm{Pb}(\mathrm{OAc})_{2}$, and quantitatively transferred to $50 \mathrm{ml}$ centrifuge tubes. The tubes were centrifuged again at $2000 \mathrm{rpm}$ for trhee minutes. The supernatants were transferred back into beakers; the precipitated protein peliets were washed with $3 \mathrm{ml} 80 \%$ EtOH and recentrifuged. The pooled oligosaccharide extracts were then transferred from the beakers to $50 \mathrm{ml}$ Erlenmeyer filter flasks and concentrated to approximately 
$20 \mathrm{ml}$ on steam baths. Excess lead was then precipitated by bubbling hydrogen sulfide* through the extracts for 10-15 seconds. The black lead sulfide precipitates were centrifuged out, the extracts transferred to $25 \mathrm{ml}$ volumetrics, and the flasks brought to volume with distilled deionized water. Approximately 0.1 gm of raffinose was added to each of ten $10 \mathrm{ml}$ volumetric flasks. These then flasks were brought to volume with the corresponding ten diluted oligosaccharide extracts to serve as "spiked" samples for quantitative purposes.

Preparation of Standard Solution

The following amounts of standards were added to a $10 \mathrm{ml}$ volumetric flask and brought to volume with deionized distilled water. The weights have been corrected for the water composition of the sugars.

*Previous attempts in this laboratory to analyze bean samples for flatulent oligosaccharides using the Black and Bagley procedures were suspended because of the apparent hydrolysis of the oligosaccharides during the sample preparation. The hydrolysis was attributed to the addition of oxalic acid, which Black and Bagley use to precipitate excess lead, to the sample extracts. Hydrogen sulfide was substituted for oxalic acid to avoid hydrolysis of the oligosaccharides. When a trial run of the entire procedure, employing the $\mathrm{H}_{2} \mathrm{~S}$ substitution, and using the same HPLC column that the original investigators used, was carried out, it was discovered that hydrolysis might still be occurring. This was concluded from the appearance of milibiose, and hydrolysis product of raffinose and stachyose, in the chromatogram. Another possibility, of course, was that melibiose was a naturally occurring oligosaccharide in the bean sample. Before either of these two possibilities could be eliminated, a new Waters HPLC carbohydrate column was obtained, and the procedure was tried out on the new column. Melibiose was not observed on the chromatogram; raffinose and stachyose were sharply resolved. In retrospect, the hydrolysis originally attributed to oxalic acid may have in fact been due to the machinations of a contaminated and much maligned column. Or, the number of theoretical plates in the old column may have been so reduced that raffinose and melibiose could not be resolved from one another and were, therefore, eluting at the same time. 
The raffinose (Difco) was assumed to be the pentahydrate; the stachyose (Sigma) was assumed to contain $4.5 \mathrm{H}_{2} \mathrm{O} / \mathrm{mole}$, as indicated by its label; the sucrose was found to be $0.05 \%$ water by weight from drying in a vacuum oven.

$\begin{array}{lc}\text { Oligosaccharide } & \text { Weight, gram } \\ \text { Sucrose } & 0.0998 \\ \text { Raffinose } & 0.0927 \\ \text { Stachyose } & 0.0986\end{array}$

Chromatographic Analysis of Extracts

The standard solution and the oligosaccharide extracts were analyzed on a Waters Associates Liquid Chromatograph with a Model M-6000 A pump and Model R401 Differential Refractometer. A Waters Carbohydrate Analysis column was used. The chromatographic conditions were as follows:

$\begin{array}{ll}\text { Sample Injection Size: } & \begin{array}{l}20 \text { microliters for Standard Solution } \\ \text { and } 50 \text { microliters for Sample Extracts }\end{array} \\ \text { Column Flow: } & 2.0 \mathrm{ml} / \mathrm{minute} \\ \text { Chart Speed: } & 0.2 \text { inches/minute } \\ \text { Attenuation: } & 4 \times \\ \text { Solvent: } & 76: 24 \text { Acetonitrile: } \mathrm{H}_{2} \mathrm{O}\end{array}$

Three injections of the standard solution were made. The peak areas of the sucrose, raffinose, and stachyose were calculated by multiplying height by width at half height. The peak areas and the response factors of the standards are given in Figures 1 and 2 , respectively. 
Fig. 1. Peak Areas of Standards, $\mathrm{cm}^{2}$ (20 microliter Injections)

\begin{tabular}{|l|c|c|c|c|}
\hline Oligosaccharide & 1 & 2 & 3 & Mean \\
\hline Sucrose & 1.38 & 1.48 & 1.50 & 1.45 \\
Raffinose & 1.09 & 1.39 & 1.24 & 1.24 \\
Stachyose & 1.36 & 1.38 & 1.35 & 1.36 \\
\hline
\end{tabular}

Fig. 2. Response Factors of Standards

\begin{tabular}{|l|c|}
\hline Oligosaccharide & Response Factor \\
\hline Sucrose & $7264.53 \frac{\mathrm{cm}^{2}}{\mathrm{gm}}$ \\
Raffinose & $6688.24 \frac{\mathrm{cm}^{2}}{\mathrm{gm}^{\mathrm{m}}}$ \\
Stachyose & $6896.55 \frac{\mathrm{cm}^{2}}{\mathrm{gm}}$ \\
\hline
\end{tabular}

After the standard solution was chromatographed, two injections of each sample extracts, followed by two injections of the corresponding raffinose spiked sample extract, were carried out. Each injection took 30 minutes to completely elute from the column. The sample weight extracted, the amount of raffinose spiked into each extract, and the peak areas of the oligosaccharides found in each extract are presented in Table 1.

\section{Results and Discussion}

The sucrose, raffinose, and stachyose contents of the bean samples are presented in Table 2. The values are in gm. per 100 of 
whole dry bean. The reported ranges of these oligosaccharides for soybean are shown for comparison (Hymowitz et al,.1972).

In general, the oligosaccharide contents of the bean samples are slightly higher but comparable to those reported for soybeans. The total oligosaccharide contents of samples 162, 163, 164, and 346 exceed the total oligosaccharide content of the soybeans examined by Hymowitz (1972). With respect to the individual sugars, the following observations can be made. Samples 162, 164, and 346 have sucrose contents greater than the sucrose contents of Hymowitz's soybeans. Samples 163, 208, 543, 544, and 545 have higher raffinose contents, and samples 162, 163, 164, 345, and 346 higher stachyose contents, than Hymowitz's soybeans. Samples 162, 163, 164, and 346 have a higher total flatulent oligosaccharide (raffinose + stachyose) content than Hymowitz's soybeans. Compared to the oligosaccharide contents of the legumes reported by Cristofaro (1972), samples 208, 543, 544, and 545 have higher raffinose contents; samples 162,163 , and 164 have higher stachyose contents.

It should be noted that samples 162 and 346 are hoth samples of the same variety of tepary bean, the white tepary bean. The percent sucrose and stachyose of 162 are greater than 346 by one; the raffinose content of 346 is a little over twice that of 162. In addition, samples 163 and 345 are both samples of the same variety of tepary bean, the brown tepary bean. The percent sucrose of 345 is greater than that of 163 by one, whereas its percent stachyose is less than that of 163 by about two. No raffinose was detected in 345; just under one percent raffinose was found in 163. Samples 543,544 , and 545 are all samples of Green Palo Verde beans. The oligosaccharide contents of 544 and 545 
agree with one another very well. Sample 543 contains approximately half the amounts of sucrose and raffinose of sample 544 and 545. 
Table 1. Chromatographic Peak Areas of 01igosaccharides

\begin{tabular}{|c|c|c|c|c|c|c|c|c|c|}
\hline \multirow{2}{*}{$\begin{array}{c}\text { Senple } \\
\text { Los } \\
\text { Number }\end{array}$} & \multirow{2}{*}{$\begin{array}{l}\text { Semple } \\
\text { Ne1ghe } \\
\text { (greme) }\end{array}$} & \multirow{2}{*}{$\begin{array}{l}\text { Added } \\
\text { Maffinose } \\
\text { (grams) }\end{array}$} & & \multicolumn{3}{|c|}{ Rew Extract $\left(\mathrm{cm}^{2}\right)$} & \multicolumn{3}{|c|}{ Splked Extract $\left(\mathrm{cm}^{2}\right)$} \\
\hline & & & & Sucrose & Raflinase & Stachyose & Sucrose & Refllg̣ose & Stachyoee \\
\hline 161 & 1.3587 & 0.0395 & $\begin{array}{c}1 \\
2 \\
\text { Hean }\end{array}$ & $\begin{array}{l}1.89 \\
1.88 \\
1.89\end{array}$ & $\begin{array}{l}0.06 \\
0.05 \\
0.06\end{array}$ & $\begin{array}{l}1.12 \\
0.90 \\
1.01\end{array}$ & $\begin{array}{l}2.03 \\
2.01 \\
2.02\end{array}$ & $\begin{array}{l}8.06 \\
7.06 \\
7.37\end{array}$ & $\begin{array}{l}1.26 \\
1.11 \\
1.18\end{array}$ \\
\hline 162 & 1.4546 & 0.0004 & $\begin{array}{c}1 \\
2 \\
\text { Mean }\end{array}$ & $\begin{array}{l}3.15 \\
3.15 \\
3.15\end{array}$ & $\begin{array}{l}0.06 \\
0.13 \\
0.11\end{array}$ & $\begin{array}{l}1.49 \\
1.49 \\
1.49\end{array}$ & $\begin{array}{l}3.60 \\
3.35 \\
3.38\end{array}$ & $\begin{array}{l}5.40 \\
3.01 \\
3.21\end{array}$ & $\begin{array}{l}1.66 \\
1.85 \\
1.76\end{array}$ \\
\hline 163 & 1.3128 & 0.0758 & $\begin{array}{c}1 \\
2 \\
\text { Hean }\end{array}$ & $\begin{array}{l}1.74 \\
1.74 \\
1.74\end{array}$ & $\begin{array}{l}0.36 \\
0.20 \\
0.28\end{array}$ & $\begin{array}{l}1.67 \\
1.53 \\
1.60\end{array}$ & $\begin{array}{l}1.74 \\
1.83 \\
1.79\end{array}$ & $\begin{array}{l}4.32 \\
4.46 \\
4.39\end{array}$ & $\begin{array}{l}1.38 \\
1.67 \\
1.53\end{array}$ \\
\hline 164 & 1.3457 & 0.0901 & $i_{\text {mean }}^{1}$ & $\begin{array}{l}2.48 \\
2.51 \\
2.50\end{array}$ & $\begin{array}{l}0.16 \\
0.08 \\
0.11\end{array}$ & $\begin{array}{l}1.70 \\
1.70 \\
1.70\end{array}$ & $\begin{array}{l}2.61 \\
2.61 \\
2.61\end{array}$ & $\begin{array}{l}4.94 \\
3.06 \\
4.99\end{array}$ & $\begin{array}{l}1.65 \\
1.69 \\
1.67\end{array}$ \\
\hline 200 & 1.4631 & 0.0011 & $\begin{array}{c}1 \\
2_{\text {Mean }}\end{array}$ & $\begin{array}{l}0.11 \\
0.73 \\
0.72\end{array}$ & $\begin{array}{l}1.26 \\
1.22 \\
1.24\end{array}$ & $\begin{array}{l}0.23 \\
0.41 \\
0.32\end{array}$ & $\begin{array}{l}0.76 \\
0.69 \\
0.72\end{array}$ & $\begin{array}{l}9.18 \\
9.20 \\
9.19\end{array}$ & $\begin{array}{l}0.38 \\
0.36 \\
0.36\end{array}$ \\
\hline 365 & 1.6223 & 0.0080 & $\begin{array}{c}1 \\
2 \\
\text { Mean }\end{array}$ & $\begin{array}{l}3.73 \\
3.15 \\
3.13\end{array}$ & $\begin{array}{l}0.00 \\
0.00 \\
0.00\end{array}$ & $\begin{array}{l}1.89 \\
1.64 \\
1.71\end{array}$ & $\begin{array}{l}3.88 \\
3.93 \\
3.91\end{array}$ & $\begin{array}{l}7.16 \\
7.18 \\
7.11\end{array}$ & $\begin{array}{l}1.69 \\
1.80 \\
1.79\end{array}$ \\
\hline 346 & 1.4842 & 0.0879 & $\sum_{\text {Mean }}^{1}$ & $\begin{array}{l}3.41 \\
3.71 \\
3.36\end{array}$ & $\begin{array}{l}0.3 n \\
0.38 \\
0.3 n\end{array}$ & $\begin{array}{l}1.76 \\
1.88 \\
1.02\end{array}$ & $\begin{array}{l}3.94 \\
3.79 \\
3.87\end{array}$ & $\begin{array}{l}7.60 \\
7.58 \\
7.49\end{array}$ & $\begin{array}{l}1.86 \\
1.19 \\
1.83\end{array}$ \\
\hline 543 & 1.4932 & 0.0892 & $\begin{array}{c}1 \\
2 \\
\text { Mean }\end{array}$ & $\begin{array}{l}0.90 \\
1.00 \\
0.95\end{array}$ & $\begin{array}{l}0.86 \\
1.04 \\
0.95\end{array}$ & $\begin{array}{l}0.00 \\
0.00 \\
n .00\end{array}$ & $\begin{array}{l}0.05 \\
1.08 \\
0.91\end{array}$ & $\begin{array}{r}10.60 \\
8.62 \\
9.61\end{array}$ & $\begin{array}{l}0.00 \\
0.00 \\
0.00\end{array}$ \\
\hline 364 & $\begin{array}{c}1.4831 \\
.\end{array}$ & 0.0882 & $\begin{array}{c}1 \\
2 \\
\text { Mean }\end{array}$ & $\begin{array}{l}1.13 \\
1.19 \\
1.17\end{array}$ & $\begin{array}{l}1.28 \\
1.14 \\
1.21\end{array}$ & $\begin{array}{l}n .00 \\
0.00 \\
0.00\end{array}$ & $\begin{array}{l}1.23 \\
1.25 \\
1.26\end{array}$ & $\begin{array}{l}6.28 \\
6.2 n \\
6.28\end{array}$ & $\begin{array}{l}0.00 \\
0.00 \\
0.00\end{array}$ \\
\hline 545 & 1.5148 & 0.0896 & $\begin{array}{c}1 \\
2 \\
\text { Mean }\end{array}$ & $\begin{array}{l}1.73 \\
1.14 \\
1.14\end{array}$ & $\begin{array}{l}1.62 \\
1.64 \\
1.63\end{array}$ & $\begin{array}{l}0.00 \\
0.00 \\
0.00\end{array}$ & $\begin{array}{l}1.74 \\
1.76 \\
1.75\end{array}$ & $\begin{array}{l}0.37 \\
8.35 \\
8.36\end{array}$ & $\begin{array}{l}0.00 \\
0.00 \\
0.00\end{array}$ \\
\hline
\end{tabular}

Sample Calculation. A anple calculat ton for the olfgosacchartile contente of eappla lok 
Table 2. Oligosaccharide Contents of Bean Samples

\begin{tabular}{|c|c|c|c|c|c|}
\hline $\begin{array}{l}\text { Log } \\
\text { No. }\end{array}$ & Sample & $\begin{array}{c}x \\
\text { Sucrose }\end{array}$ & $\stackrel{\pi}{\text { Raflinose }}$ & $\begin{array}{c}X \\
\text { stachyose }\end{array}$ & $\begin{array}{c}\text { Total } \\
\text { O11 gosaccharide }\end{array}$ \\
\hline 161 & $\frac{\text { Phaseolue }}{\text { Tepary, Tlburon Islond, Mexico }}$ & 1.80 & 0.05 & 1.10 & 2.95 \\
\hline 162 & $\frac{\text { Phaseolus acut lfollus latifollus }}{\text { Domeot Ic White Tepary }}$ & 8.42 & 0.28 & 4.61 & 13.31 \\
\hline 163 & $\frac{\text { Phaeeolua acut lfollug latifollue }}{\text { Domeotic }}$ & 5.77 & 0.98 & 5.45 & 12.20 \\
\hline 164 & $\frac{\text { Phaneolus }}{\text { Hermosilio. Mexico }}$ & 7.22 & 0.33 & 4.96 & 12.51 \\
\hline 208 & $\frac{\text { Lyallomn }}{\text { Feother }} \frac{\text { wataon } 11}{\text { ree Benn }}$ & 1.24 & 2.32 & 0.65 & 4.21 \\
\hline 345 & $\frac{\text { Plinseolua acutifollue latifollus }}{\text { Brown Tepary }}$ & 6.80 & $-\cdots$ & 3.27 & 10.07 \\
\hline 346 & $\frac{\text { Phaseolus acuctfollus latifollus }}{\text { White Tepary }}$ & 7.41 & 0.79 & 3.69 & 11.89 \\
\hline 543 & $\frac{\text { Cerclalum microphylium }}{\text { Green Palo Verde }}$ & 1.53 & 1.64 & $-\infty$ & 3.17 \\
\hline 544 & $\frac{\text { Cercldium micropliyllum }}{\text { Green Palo }}$ & 3.35 & 3.35 & $-\ldots$ & 6.90 \\
\hline \multirow[t]{3}{*}{545} & $\frac{\text { Cercldlum }}{\text { Freen Palo }} \frac{\text { leropliyllum }}{\text { Verde }}$ & 3.53 & 3.57 & -.-- & 7.10 \\
\hline & $\begin{array}{l}\text { Ranpe of Values for } \\
\text { Dean Samplea }\end{array}$ & $1.24-8.42$ & $0.05-3.57$ & $0.65-5.45$ & $2: 95-13.31$ \\
\hline & $\begin{array}{l}\text { Reported Range of Values } \\
\text { for Soybeans }\end{array}$ & $5.06-6.78$ & $0.54-0.95$ & $2.23-3.05$ & A. 30-10.11 \\
\hline
\end{tabular}




\section{CHAPTER 2}

\section{TRYPSIN INEIBITORS}

\section{Literature Reviev}

Trypsin inhibitors have been reviewed recently by Whitaker and Eeeney (1973), Liener (1976), Rackis (1978), and Iiener (1979).

It has been known for some time that the nutritive value and protein digestibility of legumes are poor unless the legumes are subjected to cooking or some other kind of heat treatment. This depression in protein value and digestibility can be attributed in part to the action of trypsin inhibitors. The reduction in digestibility is almost always accompanied by hypertrophy of the pancreas.

Chernick et al. (1948) first observed that rats and chicks fed ray soybeans or purified preparations of the inhibitor developed an enlarged pancreas resulting in increased secretion of pancreatic enzymes (Gertler et al., 1967). Lyman and Lepkovsky (1957) suggested that growth depression caused by trypsin inhibitors might be the result of an endogeneous loss of essential amino acids produced by hypersecretion of the pancreas. Since pancreatic enzymes are rich in the sulfur-containing amino acids, pancreatic hypertrophy causes the supply of these amino acids to be diverted from the synthesis of body tissue to the synthesis of pancreatic enzymes which are lost through excretion. This loss in the sulfur-containing amno acids compounds another problem, the fact 
that most legumes are low in the sulfur amino acids to begin with. Booth et al. (1960) showed that methionine supplementation will effectively counteract much of the growth depression caused by raw soybeans, despite the persistence of pancreatic hypertrophy.

Concerning the mechanism by which trypsin inhibitors actually cause pancreatic hypertrophy Green \& Lyman (1972) have suggested that the degree of pancreatic secretion is determined by the level of free trypsin present at any given time in the intestine. According to this negative feedhack mechanism, as the trypsin drops below a particular threshold level, the pancreas is induced to produce more enzyme; when the level of trypsin is restored to normal levels, the secretory activity of the pancreas is inhibited. The pancreatic stimulatory hormone, cholecystokinin, is believed to be responsible for these effects; its release from the intestinal mucosa is inhibited by free trypsin. Any situation that leads to reduction of free trypsin in the intestine, such as complexation with an inhibitor, would serve to release CCK, resulting in hypertrophy of the pancreas.

A complicating factor in the study of the effects of trypsin inhibitors and lectins (Chapter 3) on protein quality and digestibility was discovered by Kakade et a1. (1973): A comparison of the in vitro digestibility of raw soybean protein, from which the protease inhibitors had been removed by affinity chromatography, with a heat treated control revealed that the heat treated was more readily digested by trypsin. This suggests that native soy protein is in itself resistant to digestion by trypsin unless denatured by heat. 
Thompson and Liener (1978) have found that isolated globular proteins of Phaseolus vulgaris are also very resistant to attack by proteolytic enzymes. If, as Green et al. (1973) suggest, undenatured protein can bind tryp̣sin by forming an enzyme substrate complex, then this could lead to increased secretion of trypsin and result in pancreatic hypertrophy.

KrogdahI and Holm (1979) studied the effects of crude extracts of raw soybeans and purified inhibitors (Kunitz soybean trypsin inhibitor and lima bean inhibitor) on the total proteolytic activity and trypsin in human pancreatic juice. The studies were compared to the effects of these inhibitors on rat pancreatic enzymes. Extracts of 70 gram of soybean meal were able to eliminate trypsin and chymotrypsin activity in one liter of human pancreatic juice. An extract of 1 gram of soybean meal eliminated the trypsin and chymotrypsin activity from one rat pancreas while it reduces the total proteolytic activity to approximately 50\%. The inhibition of human trypsin and chymotrypsin was different from that of rat proteinases.

Madar (1979) demonstrated that the trypsin inhibitory site is essential for the development of pancreatic enlargement and for increased enzyme activity in the chick, whereas the chymotrypsin inhibitory site of the soybean Bowman-Birk trypsin inhibitor is not involved in any signigicant effect on the pancreas. (The Bowman-Birk trypsin inhibitor has active sites for the inhibition of both trypsin and chymotrypsin). Nitsan and Madar (1978) have shown that the ingestion of a raw soybean diet, or of a heated soybean diet supplemented with trypsin inhibitors, induced higher amylase activities in the lower part of the 
smaller intestine and caecum of chicks as compared with heated soybean diet. The increased amylase found in the digestive tract was determined to be of pancreatic origin.

As of 1970, 7-10 protease inhibitors, including the Bowman-Birk and Kunitz trypsin inhibitors, have been identified in soybeans. Trypsin inhibitors have been isolated from, or trypsin inhibitor activity identified in, the following species of legumes:

\begin{tabular}{|c|c|c|}
\hline Lupinus albus & Lupin Seeds & (Hove, 1979) \\
\hline Lupinus angustifolius & Lupin Seeds & (Hove, 1979) \\
\hline Phaseolus lunatus & Lima Bean & " \\
\hline Pisum sativum & Field Peas & " \\
\hline Vicia Eaba & Broad Bean & $"$ \\
\hline Phaseolus vulgaris & Kintoki Bean & (Miyoshi, 1978) \\
\hline Phaseolus vulgaris & Kidney Bean & (Rackis, 1978) \\
\hline Psophocarpus tetragonolobus & Winged Bean & (Kortt, 1979) \\
\hline Phaseolus angularis & Adzuki Bean & (Yoshikawa, 1978) \\
\hline
\end{tabular}

The molecular mechanism by which trypsin inhibitors form complexes with trypsin are discussed by Rackis (1978).

Numerous reports have appeared in the literature concerning the processing effects on trypsin inhibitor activity. Atunes and Sgarbieri (1977) reported that 25,15 , and 7.5 minutes of boiling were required for the total destruction of trypsin inhibitor activity in unsoaked, soaked (12 hours), and soaked (12 hours) and dehulled soybeans, respectively. Thirty minutes in an autoclave at $121^{\circ} \mathrm{C}$ were necessary for the total destruction of trypsin inhibitor activity in solution. 
Gupta and Wagle (1980) investigated the effects of germination on the trypsin inhibitor activity of Phaseolus mungo, $\underline{P}$. mangoreous, and $\underline{P}$. aureus. The trypsin inhibitor activity (TIU/seed) reduced from an initial level of 111.6 to $63.3,101.6$ to 51.6 and 105.0 to 60.0 , respectively, for the three beans over a period of 9 hours germination. There were initial increases in these beans up to the first 72 hours germination.

Assay Methods

One of the earliest methods for assaying trypsin inhibitor activity was the casein digestion procedure of Kunitz (1947), which involved the spectrophotometric determination of the breakdown products produced by a given concentration of trypsin in the presence and absence of the inhibitor. The fact that the rate of hydrolysis of casein by trupsin doesn't follow zero order kinetics under the conditions defined by Kunitz lead to reproducibility problems (Jacobbson, 1955; Bundy et al., 1958). Erlanger et al. (1961) first introduced the use of synthetic substrates to measure the inhibition of hydrolysis by trypsin. The hydrolysis of benzoyl-LD-arginine-p-nitroanilide (BAPA), for example, does follow a zero order reaction. Kakade et al. (1969) evaluated natural versus synthetic substrates for the determination of trypsin inhibitor activity. Rackis et al. (1974) reviewed the problems involved in measureing trypsin inhibitor activity. Kakade et al. (1974) reported a modified procedure for measuring the trypsin inhibitor activity of soy products using BAPA as substrate. The procedure outlined the proper extraction conditions for sample material to achieve maximum reproducibility. 


\section{Methodology}

The procedure of Kakade, Rackis, McGhee, and Puski (1974) was followed.

Preparation of Samples

All bean samples were ground in a Wiley Mill through a number 30 screen, defatted with hexane in a Goldfisch apparatus for ten hours, and then forced through a 100 mesh screen. Heat treated samples were autoclaved at 15 pounds pressure for one and one-half hours.

Approach to Trypsin Inhibitor Analysis

The raw samples were analyzed first. The first step was to determine the proper dilutions for the raw sample extracts. Each sample extract had to be diluted so that $1 \mathrm{ml}$ of the diluted extract effected an inhibition from $40-60 \%$ in the assay procedure. Secondly, the proper extraction time for the raw bean samples had to be determined. An assay for trypsin inhibitor áctivity versus extraction time for 1, 2, and 3 hour periods was therefore carried out. Log 163 was used for this assay. A one hour extraction was found to be sufficient. All the raw samples were then assayed for TI activity.

The analyses for the heat treated samples were carried out next. The proper dilutions for the extracts of the heat treated samples were determined as with the raw samples. Two assays of TI activity versus time of extraction were carried out; the first assay was for $1,4,6$, and 20 hours and the second was for 1, 2, and 3 hours. Log 162 was used for these two assays. For the heat treated samples, a one hour 
extraction period was again found to be suitable. All heat treated samples were then assayed for TI activity.

Preparation of Reagents

Tris Buffer. Nine-hundred and fifty $m l$ of deionized distilled water in a 1 liter beaker was heated to $37^{\circ} \mathrm{C}$ in a water bath. $2.94 \mathrm{gm}$ $\mathrm{CaCl}_{2} \cdot 2 \mathrm{H}_{2} \mathrm{O}$ followed by $6.05 \mathrm{gm}$ Tris (Trizma Base, Sigma) were dissolved in the preheated water. The $\mathrm{pH}$ was adjusted to $8.2 \pm .02$ with conc. HC1. The temperature was maintained at $37^{\circ} \mathrm{C}$ throughout the preparation of the buffer. After the $\mathrm{pH}$ stabilized, the solution was brought to final volume in a liter volumetric and then transferred to a plastic bottle; the buffèr could be stored for 2-3 months.

Trypsin Solution. Five mg trypsin (Worthington Biochemical Corp., $2 x$ crystallized salt free) was dissolved in and brought to volume with, in a $250 \mathrm{ml}$ volumetric flask, $0.001 \mathrm{M} \mathrm{HCl}$. The enzyme was stored in a brown glass bottle and refrigerated. The enzyme solution could be stored for 2-3 weeks without significant loss of activity.

Substrate Solution. Eighty mg of BAPA (Benzoyl-DL-arginine-pnitroanilide hydrochloride, Nutritional Biochemistry Corp.) was added to a test tube and dissolved in $2 \mathrm{ml}$ dimethyl sulfoxide. This was quantitatively transferred to a $200 \mathrm{ml}$ volumetric and brought to volume with tris buffer, prewarmed to $37^{\circ} \mathrm{C}$. The substrate solution was kept at $37^{\circ} \mathrm{C}$ in the water bath throughout the TI assay. The substrate solution was prepared daily. 
Assay Procedure

One gram of sample was extracted with $50 \mathrm{ml}$ of $0.01 \mathrm{~N}$ NaOH in a $100 \mathrm{ml}$ beaker with a stirring bar for one hour. The extract was then diluted so that $1 \mathrm{ml}$ of the diluted extract would inhibit the enzyme hydrolusis of the substrate from $40-60 \%$. Portions of the diluted extract were then pipetted into duplicate sets of $50 \mathrm{ml}$ Erlenmeyers according to one of the following three schemes:

Scheme A

\begin{tabular}{|l|c|c|c|c|c|c|c|}
\hline $\begin{array}{l}\text { Reaction } \\
\text { Vessel }\end{array}$ & 1 & 2 & 3 & 4 & 5 & $\begin{array}{c}\text { Reagent } \\
\text { Blank }\end{array}$ & $\begin{array}{c}\text { Sample } \\
\text { Blank }\end{array}$ \\
\hline $\mathrm{ml} \mathrm{Extract}$ & 0.0 & 0.6 & 1.0 & 1.4 & 1.8 & 0.0 & 2.0 \\
$\mathrm{ml} \mathrm{H} O$ & 2.0 & 1.4 & 1.0 & 0.6 & 0.2 & 2.0 & 0.0 \\
\hline
\end{tabular}

Scheme B

\begin{tabular}{|l|c|c|c|c|c|c|c|}
\hline $\begin{array}{l}\text { Reaction } \\
\text { Vessel }\end{array}$ & 1 & 2 & $3 \cdots$ & 4 & 5 & $\begin{array}{r}\text { Reagent } \\
\text { Blank }\end{array}$ & $\begin{array}{r}\text { Sample } \\
\text { Blank }\end{array}$ \\
\hline $\mathrm{ml}$ Extract & 0.0 & 0.4 & 0.6 & 0.8 & 1.0 & 0.0 & 1.0 \\
$\mathrm{mI} \mathrm{H} \mathrm{O}$ & 2.0 & 1.6 & 1.4 & 1.2 & 1.0 & 2.0 & 1.0 \\
\hline
\end{tabular}

Scheme C

\begin{tabular}{|l|c|c|c|c|c|c|c|}
\hline $\begin{array}{l}\text { Reaction } \\
\text { Vessel }\end{array}$ & 1 & 2 & 3 & 4 & 5 & $\begin{array}{c}\text { Reagent } \\
\text { Blank }\end{array}$ & $\begin{array}{c}\text { Sample } \\
\text { Blank }\end{array}$ \\
\hline $\mathrm{ml} \mathrm{Extract}$ & 0.0 & 0.2 & 0.4 & 0.6 & 0.8 & 0.0 & 0.8 \\
$\mathrm{~m} 1 \mathrm{H}_{2} \mathrm{O}$ & 2.0 & 1.8 & 1.6 & 1.4 & 1.2 & 2.0 & 1.2 \\
\hline
\end{tabular}


Two $\mathrm{ml}$ of the trypsin solution were then added to each reaction vessel except for the sample blank. Reaction vessels $1,2,3,4$, and 5 (in duplicate) were then placed in a gyratory water bath at $37^{\circ} \mathrm{C}$. After temperature equilibration, $5 \mathrm{ml}$ of the substrate solution were pipetted into each reaction vessel at 15 second intervals. After exactly ten minutes, each reaction vessel was quenched by adding $1 \mathrm{ml}$ of $30 \%$ acetic acid.

The sample blank was prepared by adding $5 \mathrm{ml}$ of substrate, followed by $1 \mathrm{ml}$ of $30 \%$ acetic acid, followed by two ml of trypsin, to the reaction vessel, which already contained the sample extract. The reagent blank was prepared by adding $1 \mathrm{ml}$ of acetic acid, followed by $5 \mathrm{ml}$ of substrate, to the reaction vessel already containing $2 \mathrm{ml}$ of $\mathrm{H}_{2} \mathrm{O}$ and $2 \mathrm{ml}$ of trypsin. Both the sample and reagent blanks were left at room temperature.

Each vessel, containing $10 \mathrm{ml}$ of reaction mixture, was then filtered (Whatman No. 1) into a $25 \mathrm{ml}$ Erlenmeyer. Each reaction mixture was then read in the spectrophotometer (Beckman DU Spectrophotometer with Gilford Model 252 Modernization System) at 410 nanometers against the reagent blank and corrected for with the sample blank. The enzymatic hydrolysis reaction that is blocked by trypsin inhibitor is this:

Benzoy1-DL-arginine-p-nitroanilide $\rightarrow$ Benzoyl-DL-arginine + p-nitroanilide

Scheme A was used for the raw sample extracts; it is the one described in Kakade's paper. Schemes $B$ and $C$ were devised for the heat treated samples. The extracts of the heat treated samples had very high absorbances. The amounts of extract in the sample blanks were scaled 
down to the amounts in Schemes $B$ and $C$ so that the absorbances of the sample blanks were lower than the absorbances of reaction vessels 4 and 5.

Sample Calculation

The calculation of the trypsin inhibitor activity of sample 161, raw, is illustrated here.

Sample Weight: $1.0227 \mathrm{gm}$; Dilution of Extract: . 18x; Scheme A

\begin{tabular}{|c|c|c|c|}
\hline Reaction Vessel & Absorbance ${ }^{a}$ & Mean & Corrected Absorbance \\
\hline Sample Blank & .024 & & \\
\hline $\begin{array}{l}5 A \\
5 B\end{array}$ & $\begin{array}{l}.051 \\
.057\end{array}$ & .054 & .032 \\
\hline $\begin{array}{l}4 A \\
4 B\end{array}$ & $\begin{array}{l}.115 \\
.121\end{array}$ & .118 & .101 \\
\hline $\begin{array}{l}3 A \\
3 B\end{array}$ & $\begin{array}{r}.203 \\
.208\end{array}$ & .206 & .194 \\
\hline $\begin{array}{l}2 \mathrm{~A} \\
2 \mathrm{~B}\end{array}$ & $\begin{array}{r}.307 \\
.291\end{array}$ & .299 & .292 \\
\hline $\begin{array}{l}1 \mathrm{~A} \\
1 \mathrm{~B}\end{array}$ & $\begin{array}{l}.513 \\
.501\end{array}$ & .507 & .507 \\
\hline
\end{tabular}

The corrected absorbances are calculated by dividing the amount of sample extract in the reaction vessel (refer to Scheme A) by the amount of extract in the sample blank, and multiplying this value from the absorbance of the sample blank, and subtracting this value from the absorbance of the reaction vessel.

${ }^{a}$ These absorbances have been read against the reagent blank. 


\begin{tabular}{|cc|} 
Reaction Vessel & Corrected Absorbance \\
\hline 5 & $.054-(.024 \times 1.8 / 2)=.032$ \\
4 & $.118-(.024 \times 1.4 / 2)=.101$ \\
3 & $.206-(.024 \times 1.0 / 2)=.194$ \\
2 & $.299-(.024 \times 0.6 / 2)=.292$ \\
1 & $.507-(.024 \times 0.0 / 2)=.507$ \\
\hline
\end{tabular}

The following table is then set up. One trypsin unit is defined as an increase of 0.01 absorbance units at 4.0 nanometers per $10 \mathrm{ml}$ of the reaction mixture. Trypsin inhibitor activity is expressed in terms of trypsin units inhibited (TIU).

Reaction Vessel ml Extract Abs. TU TIU TIU/ml Extract

\begin{tabular}{|llllll|}
\hline 1 & 0.0 & .507 & 50.7 & & \\
2 & 0.6 & .292 & 29.2 & 21.5 & 35.8 \\
3 & 1.0 & .194 & 19.4 & 31.3 & 31.3 \\
4 & 1.4 & .101 & 10.1 & 38.9 & 29.0 \\
5 & 1.8 & .032 & 3.2 & 47.5 & 26.4 \\
\hline
\end{tabular}

A graph of TIU/ml extract versus $m 1$ extract is plotted, and a linear regression of the line is determined. A linear regression gives the value of $39.9 \mathrm{TIU} / \mathrm{ml}$ as the vertical intercept. Remembering that the bean samples was extracted with $50 \mathrm{ml}$ base, and that the extract was diluted 18 fold, the trypsin inhibitor activity of the bean sample expressed as TIU/mg sample is:

$\frac{39.9 \mathrm{TIU} / \mathrm{ml} \times 50 \mathrm{ml} \times 18}{1.0227 \mathrm{gm}} \times 10^{-3}=35.1 \mathrm{TIU} / \mathrm{mg}$ sample 
In the case of the heat treated samples, the values of $\mathrm{TIU} / \mathrm{ml}$ Ext. were not amenable to linear regression analyses. Therefore, the average values of $\mathrm{TIU} / \mathrm{ml}$ extract for each sample were determined and used in the calculation of TIU/mg sample.

\section{Results and Discussion}

Table 3 is a summary of the trypsin inhibitor activities of the raw and heat treated bean samples. The percent inactivation of the trypsin inhibitor by heat treatment is also shown. The trypsin inhibitor activity of defatted soybean meal, determined in the same laboratory by Henderson (1980), is shown for comparison.

It is evident from Table 3 that there is a wide range of trypsin inhibitor activity in the bean samples. The trypsin inhibitor activities of the beans are all considerably less than that of soy, with the exception of the feather tree bean, which is comparable to soy. The trypsin inhibitor activity for the raw samples, in terms of $\mathrm{TIU} / \mathrm{mg}$, ranges from 2.3 to 60.4 . The activities of the heat treated samples range from 1.6 to $4.1 \mathrm{TIU} / \mathrm{mg}$. Considering only the Phaseolus vulgaris samples, the activity ranges from 11.9-35.1 TIU/mg for the raw and from $2.5-4.1 \mathrm{TIU} / \mathrm{mg}$ for the heat treates samples.

As with the lectins, the trypsin inhibitors of the Green Palo Verde beans are more resistant to heat treatment than those of the other samples. The percent inactivation of the trypsin inhibitor activity by heat treatment for samples 543, 544, and 545 ranges from $0-40 \%$. For the other samples, the range is from $68.9-92.9 \%$. 
Sotelo-Lopez et al. (1977) determined the trypsin inhibitor activities of several Mexican varieties of Phaseolus vulgaris beans using the method of Kakade et al. (1969). The trypsin inhibitor activities of the raw samples ranged from 10.0-21.3 TIU/mg, and from 1.9-2.9 $\mathrm{TIU} / \mathrm{mg}$ for cooked samples ( 2 hours cooking at Mexico City atmospheric pressure). The percentage destruction by cooking ranged from $73.4-88.1 \%$. These values are in the range of those arrived at for the tepary beans examined in the present study.

The two white tepary bean samples, 162 and 346, are in good agreement with one another. The activities for the raw samples are 17.4 and $15.4 \mathrm{TIU} / \mathrm{mg}$, and for the heat treated samples, 3.4 and 4.0 $\mathrm{TIU} / \mathrm{mg}$, for 162 and 345 , respectively. The activities of raw samples 163 and 345 , the brown teparies, are 11.9 and $18.9 \mathrm{IIU} / \mathrm{mg}$, respectively. The heat treated samples have activities of 3.7 and $3.9 \mathrm{TIU} / \mathrm{mg}$. 
Table 3. Trypsin Inhibitor Activities of Bean Samples

\begin{tabular}{|llccc|}
\hline $\begin{array}{c}\text { Log } \\
\text { No. }\end{array}$ & \multicolumn{1}{c}{ Sample } & $\begin{array}{c}\text { Raw Sample } \\
\text { TIU/mg }\end{array}$ & $\begin{array}{c}\text { Heat Treated } \\
\text { TIU/mg }\end{array}$ & $\begin{array}{c}\text { \% Inactivation } \\
\text { by Heat Treatment }\end{array}$ \\
\hline 161 & Tepary, Tiburon Island, Mexico & 35.1 & 2.5 & 92.9 \\
162 & Domestic White Tepary & 17.4 & 3.4 & 80.5 \\
163 & Domestic Brown Tepary & 11.9 & 3.7 & 68.9 \\
164 & Phaseolus vulgaris, Hermosil1o & 16.6 & 4.1 & 75.3 \\
208 & Feather Tree Bean & 60.4 & 1.8 & 97.0 \\
345 & Brown Tepary & 18.9 & 3.9 & 79.4 \\
346 & White Tepary & 15.4 & 4.0 & 74.0 \\
543 & Green Palo Verde & 2.3 & 1.6 & 30.4 \\
544 & Green Palo Verde & 2.6 & 2.8 & 0.0 \\
545 & Green Palo Verde & 4.7 & 2.8 & 40.4 \\
515 & Soybean & 62.0 & 2.4 & 96.1 \\
\hline
\end{tabular}




\section{CHAPTER 3}

\section{LECTINS}

\section{Literature Review}

The existence of lectins has been known since 1889, when Stillmark described the very toxic castor bean phytohemagglutinin, ricin. The legume group of lectins was discovered in $19 n 8$ by Landsteiner and Raubitshek (1908). Ford (1913) has reviewed the early research papers published between 1890 and 1910 on the toxicity and soecificity of lectins. Among 2663 plant species, Allen and Brilliantine (1969) detected hemagglutinating activity in 800. Lectins are proteins or glycoproteins which have the ability to bind carbohydrates. Most of the lectins isolated from different varieties of Phaseolus vulgaris have been found to have MW's ranging from 91,000 to 130,000 .

Boyd and Reguera (1949) and Renkonen (1948) discovered the existence of specific hemagglutinins for different human blood groups. Nowell (1960) described the stimulatory effect of lectins on mitosis of cultured human erythrocytes. Since Nowell's discovery, a plethora of papers dealing with the cellular biological aspects of lectins have appeared in the literature. These studies have included the induction of DNA, RNA, and protein synthesis in cell cultures; protein-carbohydrate interactions; the use of lectins in the determination of the structures of specific receptors sites on the membranes of erythrocytes and other 
cells; the specific interaction of lectins with cancer cells; the effect of lectins on immunorepression. Many studies have also been conducted on the nutritional aspects of lectins. Recent review on the subject have been written by Jaffe (1973), Lis and Sharon (1973), Liener (1974, 1976), Sequeira (1978), and Pusztai et al. (1979). The precise mechanism by which lectins produce toxic effects when eonsumed or injected into animals remains unclear. Some of the well-known toxic effects of lectins will be summarized here.

Liener and Pallansch (1952) found that the $L D_{50}$ for soybean lectins, when injected into young rats, is $50 \mathrm{mg} / \mathrm{kg}$. Soybean lectin, however, had no lethal action when administered to rats by stomach tube at a level of $500 \mathrm{mg} / \mathrm{kg}$. The $L D_{50}$ of blackbean ( $\underline{P}$ - vulgaris) lectin when injected into rats was found to be similar to that of soy (Jaffe, 1960). In contrast, however, diets containing raw black beans or orally administered black bean lectin caused weight loss and death.

The degree of toxicity of different lectins has been found to depend on the animal species used, the route of administration, and the age of the test animal. Supplementation of raw bean diets with predigested casein has been used as a method to distinguish between the effects of trypsin inhibitors and those of lectins.

Sharpless et al. (1934) discovered that raw soybeans have a goitrogenic effect on rats. This has been attributed to the inhibition by lectins of the reabsorption of thyroxine from the gut, where it is excreted via the bile. 
De Muelenaere (1964) noted that reduced amino acid absorption through the intestinal wall can be observed in rats fed raw soybeans. Neshein (1962) determined that the presence of raw soybean fractions in an experimental diet resulted in low fat absorption in rats. Animals subsisting on raw soybeans diets have demonstrated increased requirements for vitamins $A, D$, and $K$, as well as the water soluble vitamine $B_{12}$ (Jaffe, 1973).

Pusztai et al. (1979) summarized the possible reasons for the toxicity of lectins. "It has been suggested that the ingested lectin might exert its toxic effects on the recipient animals by interfering with their digestion and/or absorption, by the formation of intestinal and other lesions or by an impaiment of body defenses and the consequent tissue invasion by normally innocuous gut bacteria." To examine these possibilities, the authors carried out morphological studies, nitrogen-balance studies, and immunochemical studies on rat fed high lectin content white kidney beans or purified lectins.

Light microscopy examination of the brush borders of the duodenal and jejunal enterocytes of rats fed the diets revealed the cells to be severely disrupted. An overgrowth of bacteria occurred in the small intestines of the rats fed the bean diets; the number of bacteria associated with the disrupted brush borders of rats given the purified lectins was much reduced.

Electron microscopy examination of the same tissues demonstrated that irregularly arranged, fragmented or vesiculated microvilli were present on the apical surfaces of the duodenal and jejunal enterocytes. Often associated with the disrupted microvilli were vesiculated membranous 
debris, flocculent electron dense material, goblet cell mucins, and coliform bacteria. Changes within the enterocytes were also evident. Feeding studies showed that although the bean fed rats might absorb a similar amount of nitrogen from the diet as those on casein, in the presence of lectins the combined nitrogen content of urine and faeces could exceed that ingested and put the rats into negative nitrogen balance. In the presence of lectins the rats were apparently either less able to utilize absorbed food nitrogen or had an elevated protein catabolism.

The immunochemical studies on the bean fed rats showed that lectins were internalized by the enterocytes and taken into the blood circulatory system. Anti-lectin antibodies were produced in the rats by subcutaneous injections of pure lectin into the rats before the start of the bean feeding so that the investigators could determine whether toxic effects would occur when the lectins from the bean diets got into the rats' circulatory system. Toxic effects were still observed. The authors concluded that it was unlikely then for the observed toxicity effects to be caused simply by the appearance of lectins in the blood.

Li and Kornfeld (1977) had previously shown that lectins can cause impairment of membrane transport systems. Moser et al. (1978) had shown that lectins increased themembrane permeability for intracellular proteins. With these studies in mind, and with the results outlined above, Pusztai et al. speculated that as a result of increased membrane permeability in those cells which had reacted with the lectins in the feeding studies, "Abnormal amounts of ions, nutrients, partially 
digested, modified, or even intact and potentially toxic substances might also be absorbed." This could lead to ensuing systemic effects, such as an abnormally high rate of tissue protein catabolism, and thus explain the rats' inability to grow and develop properly.

Jaffe and Brucher (1972) have shed some light on the question of whether there is a direct correlation between a lectin's hemagglutinating ability and its toxicity. By using red blood cells from different animal species, it was possible to differentiate four types of hemagglutinating activities in the extracts from several varieties of beans.

Type A Agglutinates red blood cells of rabbit and trypsin-activated cow blood cells.

Type B Agglutinates rabbit rbc's, but not trypsinated cow rbc's.

Type C Agglutinates trypsinated cow rbc's, but not rabbits rbc's.

Type $D$ Doesn't act on rabbit or cow blood cells but agglutinates pronase treated hamster blood.

Type $A$ and $C$ bean extracts were found to be lethal when injected into mice intraperittoneally; type $B$ and $D$ extracts were not toxic.

Four groups of rats were fed diets prepared with each of the 4 types of beans. The diets contained $10 \%$ of trypsin digested casein to control for the effects of trypsin inhibitors. The rats fed diets containing type $A$ and $C$ beans lost weight and died within two weeks, those fed diets containing type $B$ and $D$ beans showed no signs of toxicity.

A previous paper by Jaffe et al. (1972), in which a wide variety of animal species were tested, showed that types A, B, and C lectins 
also agglutinate rat red blood cells. These results suggest that even though a bean lectin may have the capability to egglutinate the red blood cells of a particular species of animal, it may not necessarily be toxic to that species.

Hankins and Shannon (1978) purified the major lectin from mung bean seeds and found that it possessed alpha-galactosidase activity. Based on this finding, they postulated that legume lectins might, in general, be plant enzymes.

\section{Processing Effects}

Sgarbieri and Antunes (1977) found that complete inactivation of hemagglutinating activity in soybeans could be accomplished by heating the unsoaked beans for 45 minutes in boiling water; a soybean extract required only 7.5 minutes for inactivation.

Sotelo-Lopez et al. (1978) investigated 13 edible legumes including beans, broad beans, dry peas, and lentils, commonly consumed in Mexico. Two hours boiling completely inactivated the hemagglutinating activity of the legumes when assayed with human and cow blood; $98 \%$ inactivation occurred when assayed with rabbitt blood.

Chen et al. (1977) have studied the effect of germination on the hemagglutinating activity of bean extracts. They reported that, after 4 days of germination, the hemagglutinating activity of seeds decreased to the following percentage of ungerminated seeds:

$\begin{array}{llll}\text { Dwarf Gray Pea: } & 16.3 \% & \text { Pinto Bean: } & 0.0 \% \\ \text { Wando Pea: } & 5.1 \% & \text { Soybean: } & 3.7 \%\end{array}$


Filho et al. (1979) studied the effect of ionizing radiation on the hemagglutinating and mitogenic activity of purified lectins in isolation. They determined that a dose of $10 \mathrm{Krad}$ is needed for $50 \%$ reduction of the agglutinating capacity and $70 \mathrm{Krad}$ for $50 \%$ reduction of the mitogenic effect.

Assay Methods

Liener (1955) developed a photometric procedure for measuring the hemagglutinating activity of soybean extracts. This method was based on the observation that rabbit erythrocytes sediment at a rate which is proportional to the concentration of the lectin in an extract. Hemagglutination activity is calculated from absorbance measurements of the suspension of unsedimented cells after a given time.

The most common method for the assay of hemagglutination activity is the microtiter test, first described by Sever (1962). Serial dilutions of purified lectins or crude extracts of lectins are performed to determine the highest dilution of the lectin which will agglutinate red blood cells. The last dilution step before a distinct sediment of nonagglutinated cells is visible in the center of the wells of the microtiter plate is referred to as the titer value. Human, rabbit, and bovine blood are commonly used for the assay (Lis \& Sharon, 1972). One of the problems with the microtiter assay is the reported lack of reproducibility (Sharon \& Lis, 1973). The problem lies in the fact that the determination of the titer value can be somewhat subjective, since often times there is not a sharp break of agglutination to non-agglutination from one well to the next. A difference in titer 
value of just implies a $50 \%$ difference in how much the lectin can be diluted and still retain its hemagglutinating activity.

Kohle and Kauss (1980) have developed a method to precisely quantitate lectin activity using the hemagglutination assay in microtiter plates. This procedure supposedly eliminates the reproducibility problem. The method has been used for purified lectins. An electronic particle counter is used for the counting of non-agglutinated cells in the microtiter wells; this allows a rapid, quantitative determination of the amount of lectin required to agglutinate $50 \%$ of the countable single cells. Results are related to standard curves made with the highly stable and well defined lectin Concanavalin A.

Howard and Shannon (1977) have developed an affinity chromatography method for the quantitative determination of soybean lectin.

Ghosh et a1. (1979) have developed an enzymatic assay for the detection of nanogram quantities of lectins. The authors conjugated Hen's eggs white lysozymes with p-aminophenyl-Beta-D-galactopyranoside near the enzyme's active site. When the sugar-substituted lysozyme was incubated with castor bean lectin, the enzyme was inhibited because of binding of the lectin to the sugar. The enzyme activity upon $\underline{M}$. Luteus cells as substrate was monitored spectrophotometrically, and the amount of Inhibition was used to quantitate the amount of lectin in the system. The method is applicable to crude extracts of lectins.

\section{Methodology}

The microtiter hemagglutination assay described by Jaffe, Brucher, and Palozzo (1972) was used to examine the lectins in the bean 
samples. Hemagglutination tests, using three sources of blood, bovine, rabbit, and hamster, were performed on extracts of raw and heat treated bean samples.

Preparation of Bean Samples

The beans were ground in a Wiley Mill, defatted with hexane, and passed through a 100 mesh screen. Heat treated samples were autoclaved at 15 lbs. for $1 \& 1 / 2$ hours. Five $m 1$ of physiological saline were added to $0.5 \mathrm{gram}$ of sample in a plastic vial; the samples were extracted for two hours at room temperature in a mechanical shaker. The extracts were then transferred to $15 \mathrm{ml}$ centrifuge tubes and centrifuged approximately 15 minutes at $2000 \mathrm{rpm}$. The supernatants were collected in small glass screw top vials.

Preparation of Blood

The blood samples were purchased from Flow Laboratories. All samples arrived as $50 \%$ whole blood in Alsevers solution. The blood samples were centrifuged down and washed twice with physiological saline (In the case of the hamster blood, 4 washings were sometimes necessary to get rid of hemolyzed cells). The bovine blood was treated first with trypsin and then with pronase. The hamster and rabbit blood samples were treated with pronase only. Trypsin (Millipore Corp.) was added in the proportion of $0.1 \mathrm{mg}$ to $10 \mathrm{ml}$ of $4 \%$ Bovine Erythrocyte solution. The bovine RBC's were incubated with trypsin for one hour at room temperature in a beaker with stirring. The bovine RNC's were then centrifuged down and washed twice with the saline. The rabbit, hamster, and bovine blood samples were treated with pronase (Sigma) in the 
proportion of $1.0 \mathrm{mg}$ to $10 \mathrm{ml}$ of $4 \%$ erythrocyte suspension. As with the bovine and trypsin, the blood samples were incubated with the pronase for one hour at room temperature. The blood samples were then centrifuged down and washed twice with saline. The red blood cells were then resuspended in physiological saline to make $1 \%$ erythrocyte solutions.

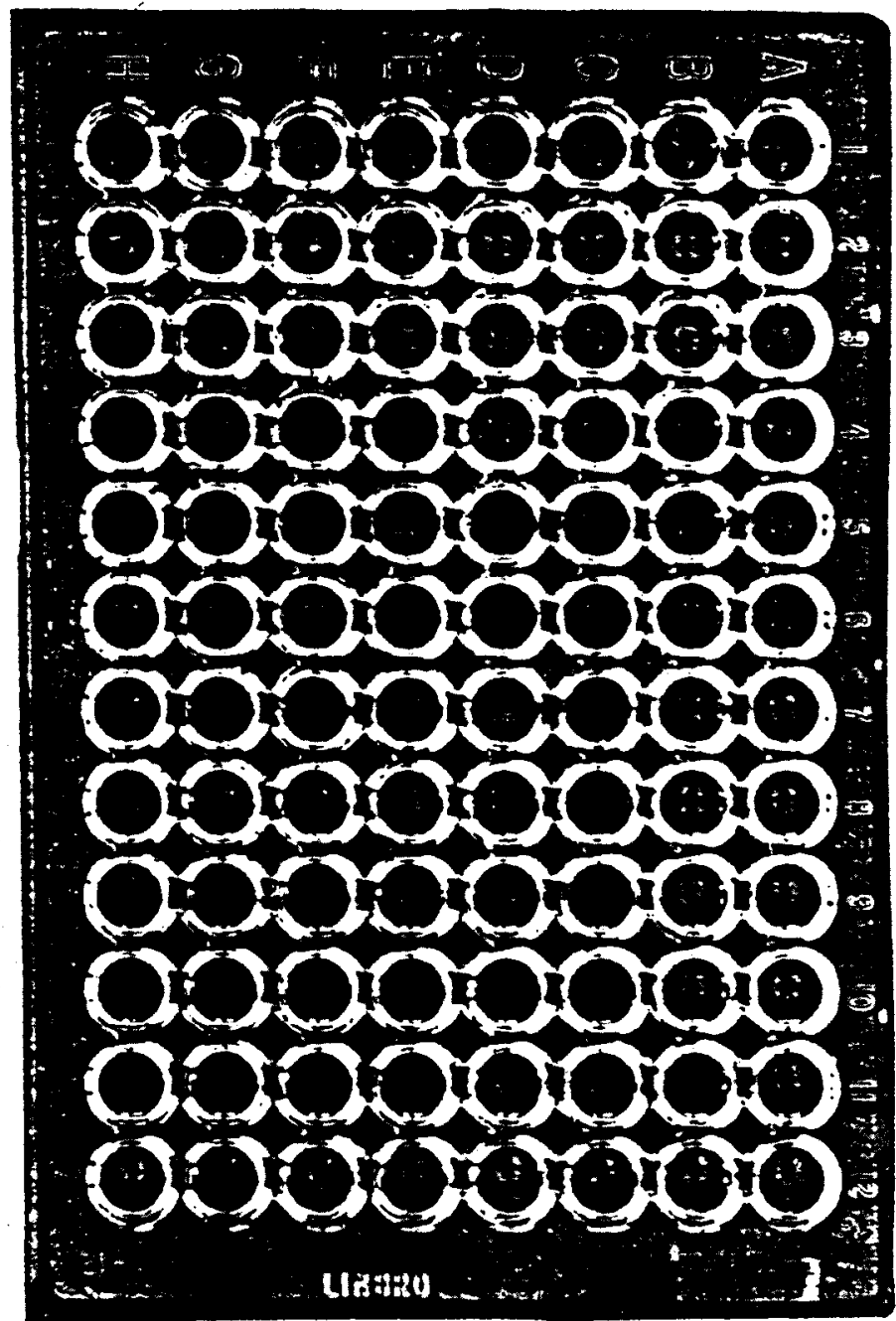

1. $25 \mu 1$ of physiological saline is added to rows 2-12 with a $25 \mu 1$ dropping pipette.

2. $50 \mu 1$ of bean extract is then pipetted into each vell of row one. (Each bean extract was assayed in dublicate so that $50 \mu 1$ of each bean extract was pipetted into each of two wells across the top row.)

3. Sertal dilutions are performed from row 1 through row 12 with 0.025 ml ricrodiluters. (Some samples had to be diluted out through 48 rows.)

4. Each well is then brought to a volume of $50 . \mu 1$ by the addition of $25 \mu l$ of saline.

5. $50 \mu 1$ of $1 \%$ red blood cell solution is then added to each well with a dropping pipette. The total volume of each well is then $100 \mathrm{Hl}$.

6. The plates are allowed to stand overnight and the agglutination patterns are recorded the next morning.

The microtiter equipment is available from Flow Laboratories. Round 
Bottom Microtitration Multi-well Plates and $0.025 \mathrm{ml}$ Diluters were used.

\section{Results and Discussion}

The results of the hemagglutination tests with the rabbit, bovine, and hamster bloods are presented in Tables 4, 5, and 6 respectively. The numbers indicate titer value, or the number of the last well in which agglutination occurred.

Table 7 shows the percent reduction of hemagglutinating activities of the bean extracts by heat treatment. Table 8 relates the titer values determined in the hemagglutination assays to the corresponding dilutions of the lectin extracts.

In the hemagglutination assays, the reproducibility between duplicates was very good. The few exceptions were samples 162, 163, and 345 with the rabbit blood, and 544 with the hamster blood.

The full hemagglutinating activities of some of the raw sample extracts were not determined because not enough blood was available to carry out further dilutions. For this reason, the percent reduction in hemagglutinating activity upon heat treatment could not be calculated for these samples. The samples in this category are 161 and 163 with the rabbit blood, 346 with the bovine blood, and 161, 162, 164, 345, and 346 with the hamster blood. The very high titer values of these particular samples are unprecendented in the literature. A titer value of 48 mesns that the lectin in 25 microliters of a sample extract can be diluted to $3.55 \times 10^{-15}$ of its concentration and still hemagglutinate 50 microliters of a one percent red blood cell solution. It is difficult to speculate what the final titer value of sample 161 with the rabbit blood would be if the hemagglutination assay were carried out to 
completion. The fact that these beans have high lectin contents should not cause an over concern for possible toxicity problems, since as evident from Table 4, heat treatment almost fully inactivates the agglutination activities of their lectin extracts. Improper cooking of the beans would, however, warrant concern for possible toxic effects upon ingestion.

The lectins of the Green Palo Verde beans appear to be more resistant to heat treatment than the other samples. The percent reduction by heat treatment ranges from 44-60\% for sample 543, 25-63\% for 544 , and $0-50 \%$ for 545 , depending on which blood type the sample was assayed with. This contrasts with the $87 \%$ or greater reduction for all the other samples.

The pronase trated hamster and rabbit red blood cells are more sensitive to hemagglutination than the trypsinated bovine rbc's. For example, the titer values for sample 208, raw are 5, 9, and 15, when bovine, rabbit, and hamster blood were used in the assay, respectively. The titer values for raw sample 164 are 21,33 , and 36 or greater with the bovine, rabbit, and hamster bloods, respectively. That the pronase treated hamster and rabbit red blood cells are more sensitive to hemagglutination than the trypsinated bovine red blood cells has been documented previously by Jaffe et al. (1972).

Sotelo-Lopez et al. (1978) used human, rabbit, and bovine blood to assay the hemagglutinating activities of several Mexican varieties of Phaseolus vulgaris beans. They reported the highest dilutions of lectin extracts ( 1 gram sample extracted with $10 \mathrm{ml} 1 \% \mathrm{NaCl}$ ) that still 
agglutinated red blood cells. Translated into approximate titer values, their results were as follows:

\begin{tabular}{|l|c|c|c|}
\multicolumn{2}{c}{} & \multicolumn{2}{c|}{ Range of Titer Values } \\
\cline { 2 - 4 } & Human Blood & Rabbit Blood & Bovine Blood \\
\hline Raw Samples & $6-16$ & $14-16$ & $0-10$ \\
Heat Treated Samples & $0-0$ & 10 & $0-0$ \\
$\begin{array}{l}\text { \% Reduction in Hemagglutinating } \\
\text { Activity from Cooking }\end{array}$ & $100 \%$ & $28-38 \%$ & $100 \%$ \\
\hline
\end{tabular}

The hemagglutinating activities of the beans studies by Sotelo-Lopez et al. are within the range of activity of the legumes examined here.

- All the beans examined in this study exhibited type A agglutinating activity. The soybean extract demonstrated type B activity. Jaffe et al. (1972) suggested that the activity of type A bean extracts could be considered the sum of $B$ and $C$ type activities, both in specific agglutination and with respect to the heat resistence of these specific agglutination activities. One would expect, then that the lectin extracts of all the bean samples would be lethal to mice if injected intraperitioneally. 
Table 4. Titer Values for Hemagglutination of Pronase-Treated Rabbit Red Blood Cells by Lectin Extracts

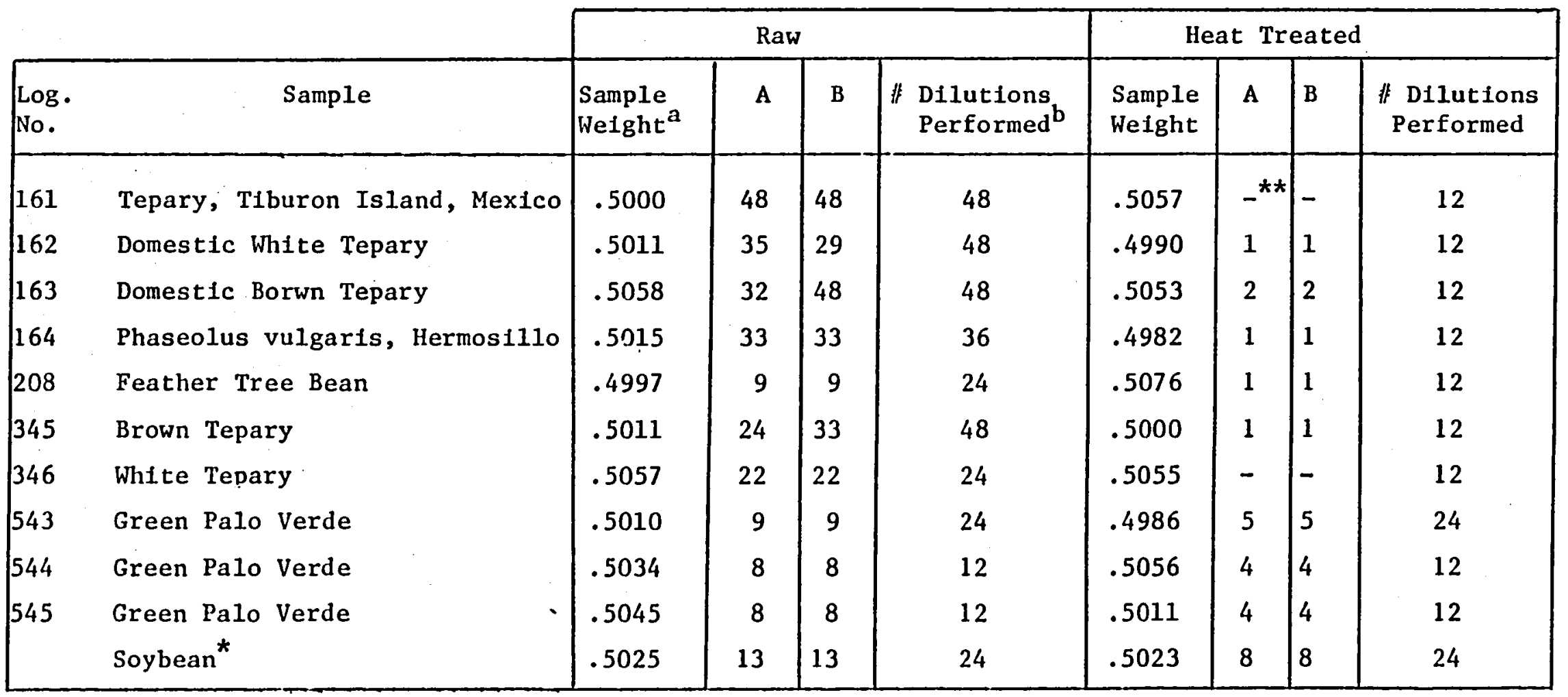

${ }^{a}$ Sample weight in grams of the defatted bean sample extracted with $5 \mathrm{ml}$ of physiological saline.

$\mathrm{b}_{\text {Numbers }}$ indicate the number of the last well through which serial dilutions performed.

* (Henderson, C. W. , Personal Communication).

${ }^{* *}$ No detectable hemagglutination occurred. 
Table 5. Titer Values for Hemagglutination of Trypsin and Pronase Treated Bovine Red Blood Cells by Lectin Extracts

\begin{tabular}{|c|c|c|c|c|c|c|c|c|c|}
\hline \multirow[b]{2}{*}{$\begin{array}{l}\text { Log. } \\
\text { No. }\end{array}$} & \multirow[b]{2}{*}{ Sample } & \multicolumn{4}{|c|}{ Raw } & \multicolumn{4}{|c|}{ Heat Treated } \\
\hline & & $\begin{array}{l}\text { Sample } \\
\text { Weight }\end{array}$ & A & B & $\begin{array}{c}\text { \#1lutions } \\
\text { Performed }\end{array}$ & $\begin{array}{l}\text { Sample } \\
\text { Weight }\end{array}$ & A & B & $\begin{array}{l}\text { \# Dilutions } \\
\text { Performed }\end{array}$ \\
\hline 161 & Tepary, Tiburon Island Mexico & .5000 & 14 & 14 & 24 & .5057 & - & - & 12 \\
\hline 164 & Phaseolus vulgaris, Hermosillo & .5015 & 21 & 20 & 24 & .4982 & - & - & 12 \\
\hline 208 & Feather Tree Bean & .4997 & 5 & 5 & 12 & .5076 & - & - & 12 \\
\hline 345 & Brown Tepary & .5011 & 23 & 22 & 24 & .5000 & - & - & 12 \\
\hline 346 & White Tepary & .5057 & 24 & 24 & 24 & .5055 & 1 & 1 & 12 \\
\hline 545 & Green Palo Verde & .5013 & 3 & 3 & 12 & .4286 & 4 & 3 & 12 \\
\hline & Soybean & .5025 & -- & -- & 12 & .5023 & - & - & 12 \\
\hline
\end{tabular}


Table 6. Titer Values for Hemagglutination of Pronase Treated Hamster Red Blood Cells by Lectin Extracts

\begin{tabular}{|c|c|c|c|c|c|c|c|c|c|}
\hline \multirow[b]{2}{*}{$\begin{array}{l}\text { Log } \\
\text { No. }\end{array}$} & \multirow[b]{2}{*}{ Sample } & \multicolumn{4}{|c|}{ Raw } & \multicolumn{4}{|c|}{ Heat Treated } \\
\hline & & $\begin{array}{l}\text { Sample } \\
\text { Weight }\end{array}$ & A & B & $\begin{array}{l}\text { \# Dilutions } \\
\text { Performed }\end{array}$ & $\begin{array}{l}\text { Sample } \\
\text { Welght }\end{array}$ & A & $\mathrm{B}$ & $\begin{array}{l}\text { Dilutions } \\
\text { Performed }\end{array}$ \\
\hline 161 & Tepary, Tiburon Island, Mexico & .5075 & 36 & 36 & 36 & .5306 & - & - & 12 \\
\hline 162 & Domest1c White Tepary & .5071 & 36 & 36 & 36 & .5067 & 1 & 1 & 12 \\
\hline 163 & Domestic Brown Tepary & .4933 & 20 & 21 & 36 & .4967 & 1 & 2 & 12 \\
\hline 164 & Phaseolus vulgaris, Hermosillo & .5070 & 36 & 36 & 36 & .5013 & 1 & 1 & 12 \\
\hline 208 & Feather Tree Bean & .5055 & 15 & 15 & 36 & .5009 & 2 & 2 & 12 \\
\hline 345 & Brown Tepary & .5066 & 36 & 36 & 36 & .4947 & 4 & 4 & 12 \\
\hline 346 & White Tepary & .4988 & 36 & 36 & 36 & .4940 & 1 & 2 & 12 \\
\hline 543 & Green Palo Verde & .5046 & 14 & 15 & 36 & .4973 & 5 & 6 & 12 \\
\hline 544 & Green Palo Verde & .5024 & 12 & 16 & 36 & .4998 & 5 & 6 & 12 \\
\hline 545 & Green Palo Verde & .5013 & 10 & 10 & 36 & .4286 & 5 & 5 & 12 \\
\hline & Soybbẹan & .5025 & 8 & 9 & 12 & .5023 & - & - & 12 \\
\hline
\end{tabular}


Table 7. \% Reduction of Hemagglutinating Activity by Heat Treatment

\begin{tabular}{|ll|c|c|c|}
\hline $\begin{array}{l}\text { Log } \\
\text { No. }\end{array}$ & \multicolumn{1}{|c|}{ Sample } & $\begin{array}{c}\text { Pronase Treated } \\
\text { Rabbit Blood }\end{array}$ & $\begin{array}{c}\text { Trypsinated Bovine } \\
\text { Blood }\end{array}$ & $\begin{array}{c}\text { Pronase Treated } \\
\text { Hamster Blood }\end{array}$ \\
\hline 161 & Tepary, Tiburon Island, Mexico & $100 \%$ & $100 \%$ & $100 \%$ \\
162 & Domestic White Tepary & 97 & 100 & $>97$ \\
163 & Domestic Brown Tepary & $>96$ & 100 & 90 \\
164 & Phaseolus vulgaris, Hermosi11o & 97 & 100 & $>97$ \\
208 & Feather Tree Bean & 89 & 100 & 87 \\
345 & Brown Tepary & 97 & 100 & $>89$ \\
346 & White Tepary & 100 & $>96$ & $>94$ \\
543 & Green Palo Verde & 44 & 50 & 60 \\
544 & Green Palo Verde & 50 & 25 & 63 \\
545 & Green Palo Verde & 50 & 0 & 50 \\
& Soybean & 38 & NA & 100 \\
\hline
\end{tabular}


Table 8. Dilutions of Lectin Extracts Corresponding to Titer Values

\begin{tabular}{|cccccc|}
\hline Titer & Dilutions & Titer & Dilution & Titer & Dilution \\
\hline 1 & 0.5 & 12 & $2.44 \times 10^{-4}$ & 29 & $1.86 \times 10^{-9}$ \\
2 & 0.25 & 13 & $1.22 \times 10^{-4}$ & 32 & $2.33 \times 10^{-10}$ \\
3 & 0.13 & 14 & $6.10 \times 10^{-5}$ & 33 & $1.16 \times 10^{-10}$ \\
4 & 0.06 & 15 & $3.05 \times 10^{-5}$ & 35 & $2.91 \times 10^{-11}$ \\
5 & 0.03 & 16 & $1.53 \times 10^{-5}$ & 36 & $1.46 \times 10^{-11}$ \\
6 & 0.02 & 20 & $9.54 \times 10^{-7}$ & 48 & $3.55 \times 10^{-15}$ \\
8 & $3.91 \times 10^{-3}$ & 21 & $4.77 \times 10^{-7}$ & \\
9 & $1.95 \times 10^{-3}$ & 22 & $2.38 \times 10^{-7}$ & \\
10 & $9.77 \times 10^{-4}$ & 14 & $5.96 \times 10^{-8}$ & & \\
\hline
\end{tabular}




\section{CHAPTER 4}

\section{PHYTIC ACID}

\section{Literature Review}

The proper chemical designation of phytic acid is myo-inositol $1,2,3,4,5,6$-hexakis (dihydrogen phosphate). The precise structure of phytic acid is still not certain; the two most likely are the Anderson (1914) and Neuberg (1908) structures. Most evidence points to the Anderson model (Erdman, 1979).

Dodecasodium phytate in crystals has the conformation with 5 phosphate groups axial and one equatorial. Phytic acid is the chief storage compound of phosphorus in plants. The phytate of plant seeds is contained primarily in the bran and germ. Phytic acid in beans has been found to occur in a water soluble form (Lolas and Markakis, 1977). Phytic acid in nutrition has been reviewed by Oberleas (1973), Davies (1979), and Erdman (1979).

Phytate has been of interest to animal scientists since McCance and Widdowson (1942) showed that phytate decreased the absorption and urinary excretion of calcium. Lațer, and more significantly, O'Dell and Savage (1960) showed that phytate decreases the bioavailability of zinc in diets fed to animals. This phenomenon has also been confind in man, pigs, rats, and chicks. Other minerals whose absorption are thought to be decreased because of formation of insoluble salts with phytate in 
the gastrointestinal tract are $\mathrm{Mg}, \mathrm{Cu}, \mathrm{Fe}$, and $\mathrm{Mn}$ (Davies, 1979).

Oberleas (1973) has summarized some of the chemical characteristics of phytate. Phytate is a strong acid that forms salts with several heavy metals. Whether or not a particular salt is formed depends on the $\mathrm{pH}$ as well as the presence of secondary cations. Ferric and scandium phytates are least soluble in dilute acid and dissociate in concentrated acid or dilute alkali. zinc and copper phytates are least soluble at $\mathrm{pH}$ values between 4 and 7 . Calcium, magnesium, and barium phytates form best under slightly alkaline conditions. Studies on titration curves of phytate as the free acid and as the sodium salt in the presence of single divalent cations have lead to the following results: At $\mathrm{pH} 7.4$ phytate formed complexes with metals in the following decreasing order:

$$
\mathrm{Cu}^{2+} \mathrm{Zn}^{2+} \mathrm{Co}^{2+} \mathrm{Mn}^{2+} \mathrm{Fe}^{3+} \mathrm{Ca}^{2+}
$$

Two or more cations, when present simultaneously, can act synergistically to increase the quantity of metallic phytate precipitated. This has been demonstrated only for zinc and calcium and for copper and calcium (Oberleas, 1966).

Studies (Koepke and Stewart, 1967; Murray and Stein, 1970) have shown that phytate decreases iron availability by decreasing the complexing of iron with gastroferrin in the stomach.

Davies and Olpin (1979) have conducted studies on the effects of phytate on trace metal solubility in vitro. In one experiment, the amounts of zinc, copper, and manganese remaining in solution at pH 6.3 as affected by increasing phytate concentration were determined. In 
the case of zinc, the percentage remaining in solution in the presence of phytic acid differed as the phytate: $\mathrm{Zn}$ ratio was increased from $10: 1$ to $45: 1$. Even at the lowest ratio $(10: 1)$, approximately $98 \%$ of the $\mathrm{Zn}$ was rendered insoluble. For both $\mathrm{Cu}$ and $\mathrm{Mn}$, in contrast, Increasing the amount of added phytate caused a corresponding decreased solubility of these two metal ions. In a second experiment, the amounts of zinc, copper, and manganese remaining in solution at $\mathrm{pH} 6.3$ in the presence of phytate as affected by decreasing zinc concentration (10:1 to 45:I phytate: zinc) were determined. The percentages of $\mathrm{Cu}$ and $\mathrm{Mn}$ remaining in solution were constant indicating that no complexation occurred between zinc and these other elements, for binding by phytate. Taylor and Coleman (1979) carried out balance studies with rats and golden hamsters given diets high and low in calcium and high and low in phytate. Values for calcium absorption and phytate availability (relative to the amount ingested) and for urinary excretion of calcium and phosphorus were significantly higher in the hamster than in the rat for all four diets. Phytate availability was significantly greater on the low calcium than on the high calcium diets with both species.

Phytate tends to become concentrated in proteins isolated from soybeans and other legumes (Smith and Circle, 1978). Atwal et al. (1980) conducted a trhee week growth study using rapeseed protein concentrates and phytate rapeseed protein concentrated at a level of $15 \%$ protein, in which phytic acid varied from 0.01 to $1.24 \%$ of the diet, in the presence of 12 parts per million mineral zinc supplementation. The performance of the rats was found to be inversely related to the level of phytic acid in the diets with significant difference observed for weight gain, diet 
consumption, and efficiency of protein utilization. Dietary phytate hade a pronounced effect on femur zinc, which decreased almost 3 fold as phytic acid increased from 0.01 to $1.24 \%$ of the diet.

The ability to hydrolyze phytate in the intestine varies with each species. Young chicks hydrolyze only small amounts of phytate for example, whereas cattle and sheep hydrolyze most of the natural phytate because of microbial phytase in the rumen. Hydrolysis of natural phytate in the rat intestine is influenced by vitamin $D$ and the level of calcium in the diet. Talmadge and Kirby (1979) conducted balance trials to determine the effect of age and diet composition on the ability of rats to hydrolyze phytate phosphorus. Weanling and mature rats hydroIyze 71 and $39 \%$ of the phytate phosphorus in a corn-soybean meal based diet, respectively. Replacing one half of the corn in the diet with wheat increased phytate hydrolysis in weanling rats from 71 to $78 \%$ and In mature rats from 27 to $41 \%$. The increased hydrolysis of phytate upon replacement of corn with wheat can probably be attributed to the fact that wheat contains phytase.

Lolas and Markakis (1977) have purified phytase from navy beans. They described the enzyme as a nonspecific phosphomonoesterase with phytase and potent pyrophosphatase activities. It was inhibited by high concentrations of phytic acid. Soaking of the beans in distilled water didn't affect their phytic acid content and phytase activity. Germination of the beans did, however, result in an increase in phytase activity and breakdown of phytic acid.

A simple procedure for decreasing the phytate content of beans has been examined by Chang et al. (1977). The authors determined that 
California small white beans contain about $1 \%$ phytate, of which $70 \%$ is in water soluble form. Incubation of the presoaked beans in water at $60^{\circ} \mathrm{C}$ for ten hours lowered their phytate content by $90 \%$. Incubation in a $\mathrm{pH} 5.5$ buffer at $50^{\circ} \mathrm{C}$ for 24 hours lowered it by $62 \%$. When leaching was eliminated by incubating in water saturated air at $60^{\circ} \mathrm{C}$ overnight, $33 \%$ of the phytate was destroyed by hydrolysis. Similar treatments were effective with mung beans, lima beans, and wheat. Several papers have appeared recently dealing with the removal of phytate from isolated soy protein. These include Ford et al. (1977), Omosaiye and Cheryan (1979), Hartman (1979), de Rham and Jost (1979), and Davies and Reid (1979).

Methods of Analysis

One of the earliest methods for the determination of phytic acid was developed by Heuber and Stadtler (1914). This was based upon the principle that ferric lon forms a stable complex with phytate in dilute acid and is supposedly the only phosphate compound in significant concentration in nature with this property. They titrated the phytate containing extracts with standardized ferric chloride solution using ammonfum thiocyanate as an internal indicator.

This method has been modified by Young (1936), McCance and Widdowson (1935), and delange (1961).

Babakhadzhaeva et al. (1968) have used an amperometric method based on the precipitation of phytate with lead nitrate and the ability of the lead fon to be reduced on a dropping mercury electrode. 
Another approach to the analysis of phytate is to hydrolyze the Inositol free of phosphate and analyze the hydrolyzate for inositol. The inositol free of phosphate and analyze the hydrolyzate for inositol. The inositol can be determined by both microbiological methods (Mckibbin, 1959) and chemical methods (Eagle et al., 1960).

More recently, Harland and Oberleas (1977) have developed a method in which phytate from an $1.2 \%$ hydrochloric acid extract of sample material is concentrated on an anion exchange resin, the contamInating inorganic phosphorus is stripped from the column with $0.05 \mathrm{M} \mathrm{NaCl}$ and the phytate then eluted with $0.7 \mathrm{M} \mathrm{NaCl}$. The $0.7 \mathrm{M}$ eluate is then digested, inorganic phosphorus is measured colorimetrically, and the phytate equivalent calculated from the hydrolyzed phosphate.

\section{Methodology}

A slight modification of the procedure of Harland and Oberleas (1977) was used to analyze the bean samples for phytic acid. In the orfginal procedure, the protocol for separating inorganic phosphorus from phytate via the ion exchange column is this: $2 \mathrm{ml}$ of an approprlately diluted sample extract is pipetted onto the anion exchange resin. Inorganic phosphorus is eluted off the column with $15 \mathrm{ml} \mathrm{H}_{2} \mathrm{O}$ followed by $15 \mathrm{ml} 0.05 \mathrm{M} \mathrm{NaCl}$. The phytate is then eluted off the column with $17 \mathrm{ml} 0.7 \mathrm{M} \mathrm{NaCl}$. Pre-testing of this procedure with a standard solution of potassium phosphate and the sodium salt of phytic acid revealed that some of the inorganic phosphorus was eluting off with the $0.7 \mathrm{M} \mathrm{NaCl}$. From a personal communication with Thompson, it was learned that the bleeding problem could be rectified simply by eluting 
the inorganic phosphorus with $15 \mathrm{ml} \mathrm{H}_{2} \mathrm{O}$ followed by $30 \mathrm{ml}$ of $0.05 \mathrm{M}$ $\mathrm{NaCl}$. The phytate was then eluted off with $17 \mathrm{ml} 0.7 \mathrm{M} \mathrm{NaCl}$ as in the orfginal procedure.

Materials

Analytical Grade anion exchange resin, Ag-1-X8, 200-400 mesh chloride form, was obtained from Bio-Rad Laboratories.

Glass barrel econo-column, $0.7 \mathrm{~cm}$ in diameter and $1.7 \mathrm{~cm}$ in length, were also purchased from Bio-Rad Laboratories.

The sodium salt of phytic acid, isolated from corn, was obtained from Sigma. The phytate was $12 \% \mathrm{H}_{2} \mathrm{O}$ by weight and of $97 \%$ purity.

Phosphorus Determination

The colorimetric method of Koenig and Johnson (1942) was used to determine phosphorus. Aliquots containing inorganic phosphorus are reacted with molybdic acid to form phosphomolybdic acid, which is, in turn reduced by ferrous sulfate to molybdenum blue. Molybdenum blue is measured spectrophotometrically at $660^{\circ} \mathrm{nm}$.

Testing of Procedure with Standards

A phosphorus/phytate solution containing 9.3333 micrograms $\mathrm{P} / \mathrm{ml}$ and $0.0288 \mathrm{mg}$ Phytate/ml was prepared (The water content and purity of the phytate salt was taken into consideration). Five ml of the phosphorus/phytate solution were pipetted onto each of six columns. The inorganic phosphorus was eluated off with $15 \mathrm{ml} \mathrm{H}_{2} \mathrm{O}$ followed by $30 \mathrm{ml} 0.05 \mathrm{M} \mathrm{NaCl}$. The inorganic phosphorus eluates were collected in $50 \mathrm{ml}$ volumetrics and brought to volume with water. The phytate was 
eluted off with $18 \mathrm{ml} 0.7 \mathrm{M} \mathrm{NaCl}$ and collected in $30 \mathrm{ml} \mathrm{Kjeldahi-fiasks.}$ To each $\mathrm{K}$ flask was added $0.5 \mathrm{ml}$ conc. $\mathrm{H}_{2} \mathrm{SO}_{4}$ and $3.0 \mathrm{ml}$ conc. HNo 3 plus bolling stones. The flasks were digested on a Kjeldahl apparatus for one to one and one-half hours. At about thirty minutes into the digestion process, the eluates would turn light orange and orange fumes would be given off. The digests would gradually become clear again. Typically, in a matter of 5-10 minutes after the orange color disappeared, the salt would precipitate out of solution, and in 2-3 more minutes, the orange fumes would appear for the secand time. The flasks were removed from the burners approximately 5 minutes after the salt precipitated out of solution. Approximately $20 \mathrm{ml}$ of $\mathrm{H}_{2} \mathrm{O}$ was added to each flask after removal from the burner; each flask was then placed in a boiling water bath for 15 minutes to hydrolyze pyrophosphates. The digests were then quantitatively transferred to $25 \mathrm{ml}$ volumetrics and brought to volume with $\mathrm{H}_{2} \mathrm{O}$. Five $\mathrm{ml}$ aliquots of the diluted phytate digests and $8 \mathrm{ml}$ aliquots of the inorganic phosphorus eluates were pipetted into $10 \mathrm{ml}$ volumetric test tubes, brought to volume with the appropriate reagents, and read in the spectrophotometer at $660 \mathrm{~nm}$ (Each standard was read in duplicate).

The sodium salt of phytic acid $\left(\mathrm{C}_{6} \mathrm{H}_{9} \mathrm{Nag}_{9} \mathrm{O}_{24} \mathrm{P}_{6}\right)$ is $21.68 \%$ phosphorus by welght. The total amounts of inorganic phosphorus and phytate pipetted onto each column were $0.0467 \mathrm{mg}$ and $0.1438 \mathrm{mg}$, respectively. The percent recoveries of inorganic phosphorus for the six standards are presented in Table 9. The percent recovereis of phytate for the six standards are presented in Table 10. 
Table 9. \% Recoveries for Inorganic Phosphorus

\begin{tabular}{|c|c|c|c|c|c|}
\hline Standard & Abs. $660 \mathrm{~nm}$ & Abs. & $\mathrm{K}(\mathrm{Abs} / \mu \mathrm{g} / \mathrm{ml})$ & Total P, mg & \% Recovery \\
\hline $1 \mathrm{~A}$ & 0.088 & .088 & .119 & .0462 & 98.93 \\
\hline $1 \mathrm{~B}$ & .087 & & & & \\
\hline $2 \mathrm{~A}$ & 0.088 & .089 & .119 & .0467 & 100.00 \\
\hline $2 B$ & .090 & & & & \\
\hline $3 A$ & .089 & .091 & .119 & .0478 & 102.74 \\
\hline $3 B$ & .093 & & & & \\
\hline $4 \mathrm{~A}$ & .085 & .086 & .119 & .0452 & 96.72 \\
\hline $4 B$ & .087 & & & & \\
\hline $5 \mathrm{~A}$ & .085 & .088 & .119 & .0462 & 98.93 \\
\hline $5 B$ & .090 & & & & \\
\hline $6 A$ & .089 & .091 & .119 & .0478 & 102.34 \\
\hline $6 B$ & .092 & & & & \\
\hline
\end{tabular}


Table 10. \% Recoveries of Phytate from Phytate/Pi Standards

\begin{tabular}{|c|c|c|c|c|c|c|}
\hline Standard & $\mathrm{Abs}_{660}$ & Abs & $\mathrm{K}$ & Total P, mg & Total Phytate, mg & \% Recovery \\
\hline $1 \mathrm{~A}$ & .081 & .080 & .119 & .0336 & .1550 & 92.07 \\
\hline $1 B$ & .078 & & & & & - \\
\hline $2 \mathrm{~A}$ & .081 & .081 & .119 & .0340 & .1570 & 93.22 \\
\hline 2B & .081 & & & & & \\
\hline $3 \mathrm{~A}$ & .085 & .085 & .119 & .0357 & .1647 & 97.82 \\
\hline $3 B$ & .085 & & & & & \\
\hline $4 \mathrm{~A}$ & .078 & .082 & .119 & .0345 & .1589 & 94.37 \\
\hline 4B & .085 & & & & & \\
\hline $5 \mathrm{~A}$ & .085 & .083 & .119 & .0354 & .1634 & 97.05 \\
\hline $5 B$ & .080 & & & 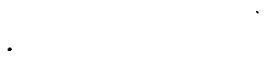 & & \\
\hline $6 \mathrm{~A}$ & .074 & .079 & .119 & .0332 & .1531 & 90.92 \\
\hline $6 \mathrm{~B}$ & .084 & & & & & \\
\hline & & & & & \multicolumn{2}{|c|}{ Mean \% Recovery $=94.24$} \\
\hline
\end{tabular}

Total P, mg $=\frac{\frac{\text { Abs }}{R} \times \frac{10}{5} \times 25}{1000}$

Total Phytate, mg $=\frac{\text { Total P, mg }}{.2168}$

$\%$ Recovery $=\frac{\text { Total Phytate, mg }}{0.1684} \times 100$ 
Pre-testing of Procedure Using Original Protocol of Harland and Oberleas The percent recoveries of inorganic phosphorus passed through the anion exchange columns using the original protocol of Harland and Oberleas are presented in Table 11. Five $m 1$ of a Phytate/Inorganic phosphorus standard were pipetted onto each of six columns. The inorganic phosphorus was eluted with $15 \mathrm{ml} \mathrm{H} \mathrm{H}_{2} \mathrm{O}$ followed by $15 \mathrm{ml} 0.05 \mathrm{M} \mathrm{NaCl}$; phytate eluates were collected in graduated cylinders. Two ml aliquots were taken from the phytate eluate to determine the inorganic phosphorus present before digestion of the phytate.

It is evident from the data that a significant amount of the inorganic phosphorus, 28.9-44.9\%, was eluting off with the phytate. This would lead to inaccurately high values for phytic acid in test samples.

It is possible that the intact phytate present in the aliquots from the undigested phytate eluates formed colored products with molybdate in the spectrophotometric determination of phosphorus concentration. This could lead to higher absorbance readings at $660 \mathrm{~nm}$ and thus inaccurately high values for the amounts of $\mathrm{Pi}$ bleeding off into the phytate eluates. However, a comparison of the phytic acid values for three bean samples obtained by a previous investigator according to the original procedure and the values obtained by the modified procedure seems to support the data in Table 11.

The percent differences between the two sets of data, 28.08$30.99 \%$, fall in the ranges of $28.0-44.9 \%$, the range of percentage of $\mathrm{Pi}$ eluting off with the $0.7 \mathrm{M} \mathrm{NaCl}$ eluate. 
Table 11. \% Recoveries of $\mathrm{PI}$ and Phytate from Original Procedure of Harland

\begin{tabular}{|l|c|c|c|c|c|c|}
\hline & A & B & C & D & E & F \\
\hline $\begin{array}{l}\text { Phosphorus added to } \\
\text { Column, mg }\end{array}$ & 0.047 & 0.047 & 0.047 & 0.047 & 0.047 & 0.047 \\
\hline Total P recovered, mg & 0.052 & 0.040 & 0.047 & 0.045 & 0.049 & 0.048 \\
\hline $\begin{array}{l}\% \text { Recovery } \\
\text { \% of Recovered P found } \\
\text { in Pi Eluate }\end{array}$ & 71.15 & 60.00 & 55.32 & 71.11 & 55.10 & 58.33 \\
\hline $\begin{array}{l}\% \text { of Recovered P found } \\
\text { in Phytate Eluate }\end{array}$ & 28.85 & 40.00 & 44.68 & 28.89 & 44.90 & 41.67 \\
\hline
\end{tabular}

Table 11. . Phytic Acid Contents, Original Versus Modified Procedure

\begin{tabular}{|cccc|}
\hline Sample & $\begin{array}{c}\text { Phytic Acid } \\
\text { gm/100 gm } \\
\text { Original Procedure }\end{array}$ & $\begin{array}{c}\text { Phytic Acid } \\
\text { gm/100 gm } \\
\text { Modified Procedure }\end{array}$ & $\%$ Difference \\
\hline 161 & 1.31 & 1.0228 & $28.08 \%$ \\
162 & 0.93 & 0.7138 & $30.99 \%$ \\
163 & 0.81 & 0.6301 & $28.57 \%$ \\
\hline
\end{tabular}


Determination of Inorganic Phosphorus and Phytic Acid in Bean Samples The bean samples were grown in a Wiley Mill and then forced through a 100 mesh screen. One-half gram of each sample was weighed out into a $25 \mathrm{ml}$ Erlenmeyer and extracted with $10 \mathrm{ml}$ of $1.2 \% \mathrm{HCl}$ for two hours in a gyratory water bath at $37^{\circ} \mathrm{C}$. The extractions were carried out in duplicate. The extracts were then centrifuged. The supernatants were filtered through Whatman No. I paper; $5 \mathrm{ml}$ of each filtered extract was pipetted into a $25 \mathrm{ml}$ volumentric and brought to volume with water. (In the case of 543,544 , and 545 , the supernatants would not pass through the filter paper, and so the unfiltered extracts were pipetted into the volumetrics.) Two $\mathrm{ml}$ of each diluted extract was pipetted onto a column. The procedure was now continued as described for the standards.

As with the standards, $8 \mathrm{ml}$ of the,diluted $\mathrm{PI}$ eluates and $5 \mathrm{ml}$ of the digested phytate eluates were pipetted into $10 \mathrm{ml}$ volumetric test tubes for colorimetric determination of phosphorus.

Simple Calculation

The percent inorganic phosphorus and phytic acid of sample 161A are calculated here. An amount of sample equal to 0.4992 gram was extracted with $10 \mathrm{ml}$ of acid.

Inorganic Phosphorus:

$$
\text { Abs }=.022 \quad \mathrm{R}=.115\left(\frac{\mathrm{Abs}}{\mu \mathrm{g} / \mathrm{ml}}\right)
$$

$$
\frac{\frac{.022}{.115} \times \frac{10}{5} \times 50}{\frac{1000}{2}} \times \frac{25}{5} \times 10
$$

$$
\begin{aligned}
& =\frac{.4783 \mathrm{mg} \mathrm{P}}{.4992 \mathrm{gm} \text { sample }} \\
& =\frac{0.958 \mathrm{gm} \mathrm{P}}{100 \mathrm{gm} \text { sample }}
\end{aligned}
$$


Phytic Acid:

$\mathrm{Abs}=.133$

$\mathrm{K}=.115$

$$
\begin{aligned}
& \underline{.133} \times \frac{10}{5} \times 25 \\
& \frac{1000}{2} \times 25
\end{aligned}
$$

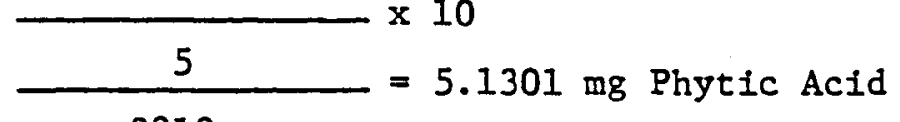

$$
\begin{aligned}
& .2818 \\
& \frac{5.1301 \mathrm{mg} \text { P. A. }}{4.992 \mathrm{gm} \text { Sample }} \times 100=\frac{1.0277 \mathrm{gm} \text { Phytic Acid }}{100 \mathrm{gm} \text { Sample }}
\end{aligned}
$$

This calculation assumes Phosphorus is $28.18 \%$ of Phytic Acid by weight.

\section{Results and Discussion}

The raw data for the inorganic phosphorus and phytic acid analyses are presented in Table 12 and 13. The mean values for inorganic phosphorus and phytic acid are presented in Table 14.

In Table 12, there is good agreement among the duplicates and triplicates upon the percent inorganic phosphorus in the bean samples. The one exception is sample 345. In Table 13, there is good agreement again, among the duplicates and triplicates upon the percent pintic acid in the samples. The two exceptions are 544 and 545.

The inorganic phosphorus and phytic acid values for soy are for defatted soy meal. The phytic acid value for soy reported here falls within the range of $1.4-1.6 \%$ listed by Erdman (1979) for the phytic acid content of soybean meal, full fat or defatted and dehulled. 
The phytic acid contents of all the bean samples are less than that of soy; moreover, most of the samples contain only about one-half the phytic acid content of soy. Chang (1977) found the phytic acid content of California small white beans, a Phaseolus vulgaris bean, to be $1 \%$. The range of the phytic acid content of the beans studied here is $0.48-1.02 \%$.

The phytic acid contents of the two samples of white teparies, 162 and 346 , are very close to one another- $0.71 \%$ and $0.75 \%$, respectively. Likewise, the phytic acid content of the two brown teparies, 163 and 345 , agree with one another very well--0.63\% and $0.60 \%$, respectively. The three samples of green Palo Verde beans also have similar phytic acid contents--0.76\%, $0.74 \%$, and $0.70 \%$ for 543,544 , and 545 , respectively. 
Table 12. Inorganic Phosphorus Analyses

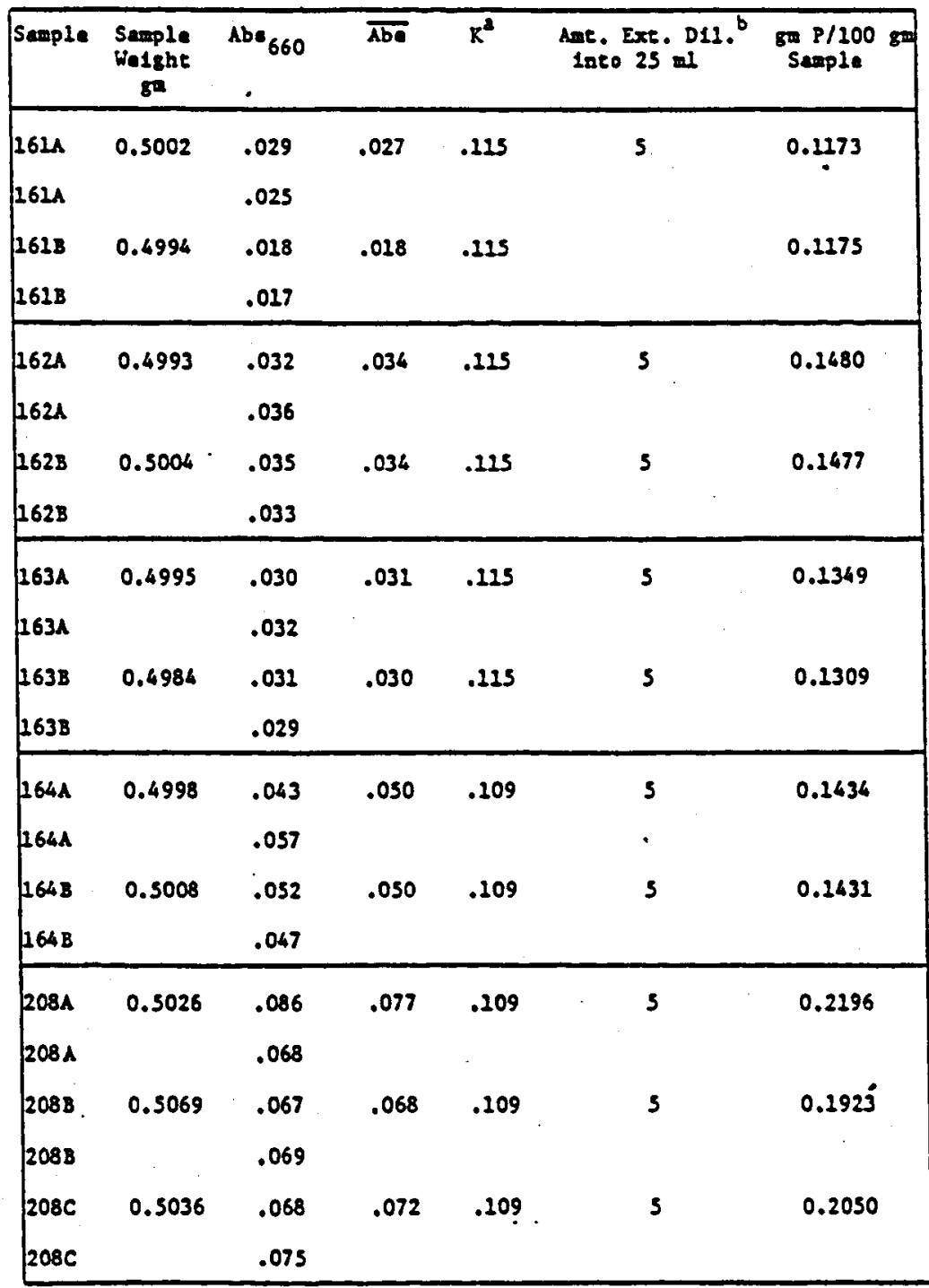


Table 12. --Continued

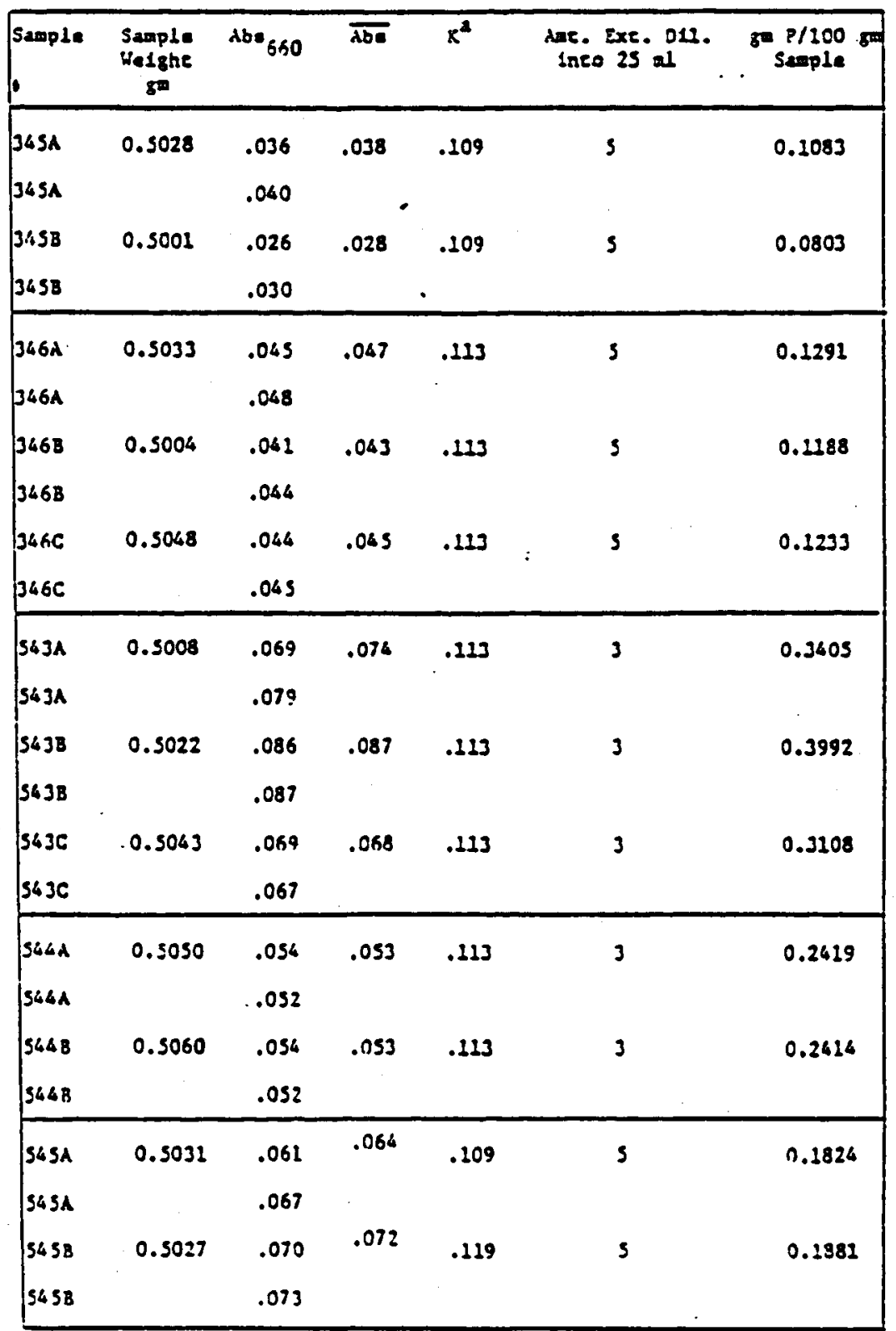


Table 12. --Continued

\begin{tabular}{|c|c|c|c|c|c|c|}
\hline Semple & $\begin{array}{c}\text { Sample } \\
\text { Wiaghe } \\
\text { ge }\end{array}$ & $A b *_{660}$ & $\overline{\mathrm{Ab} \bullet}$ & $R^{2}$ & $\begin{array}{l}\text { Ane. Exe. D11. } \\
\text { Inco } 25 \text { al }\end{array}$ & $\begin{array}{l}\text { gin P/100 } \\
\text { 8xim Semple }\end{array}$ \\
\hline $\operatorname{sos} A$ & 0.5026 & .126 & .124 & .109 & 5 & 0.3337 \\
\hline Soy $A$ & & .122 & & & & \\
\hline 5073 & 0.5039 & .110 & .107 & .109 & 3 & 0.3044 \\
\hline Soy $B$ & & .104 & & & & \\
\hline Soy C & 0.5011 & .118 & .218 & .109 & 5 & 0.3376 \\
\hline Sor C & & .118 & & & & \\
\hline
\end{tabular}

$R$ - Abs

aterogram R/mil

b Amount of Exerace Dilued loco 23 al $\mathrm{B}_{2} \mathrm{O}$. 
Table 13. Phytic Acid Analyses

\begin{tabular}{|c|c|c|c|c|c|c|}
\hline Sample & $\begin{array}{l}\text { Sample } \\
\text { Weight }\end{array}$ & $\mathrm{Abs}_{660}$ & $\overline{\mathrm{Abs}}$ & $\mathrm{K}^{\mathrm{a}}$ & $\begin{array}{l}\text { Amt. Ext. } \\
\text { Dil. }\end{array}$ & $\begin{array}{l}\text { gm Phytic Acid/ } \\
100 \mathrm{gm}\end{array}$ \\
\hline $161 \mathrm{~A}$ & 0.4992 & .131 & .133 & .115 & 5 & 1.0277 \\
\hline $161 \mathrm{~A}$ & & .134 & & & & \\
\hline $161 \mathrm{~B}$ & 0.5002 & .136 & .132 & .115 & 5 & 1.0179 \\
\hline 161 B & & .128 & & & & \\
\hline $162 \mathrm{~A}$ & 0.5004 & .094 & .097 & .115 & 5 & 0.7169 \\
\hline $162 \mathrm{~A}$ & & .092 & & & & \\
\hline 162 B & 0.4993 & .094 & .092 & .115 & 5 & .07107 \\
\hline $162 \mathrm{~B}$ & & .089 & & & & \\
\hline $163 \mathrm{~A}$ & 0.4995 & .078 & .079 & .115 & 5 & 0.6101 \\
\hline $163 \mathrm{~A}$ & & .079 & & & & \\
\hline $163 \mathrm{~B}$ & 0.4984 & .083 & .084 & .115 & 5 & 0.6501 \\
\hline $163 \mathrm{~B}$ & & .085 & & & & \\
\hline $164 \mathrm{~A}$ & 0.5011 & .062 & .060 & .113 & 5 & 0.4700 \\
\hline $164 \mathrm{~A}$ & & .057 & & & & \\
\hline 164 B & 0.4998 & .062 & .060 & .109 & 5 & 0.4885 \\
\hline 164 B & & .057 & & & & \\
\hline 208 A & 0.5026 & .122 & .124 & .109 & 5 & 1.0040 \\
\hline $208 \mathrm{~A}$ & & .125 & & & & \\
\hline 208 B & 0.5069 & .118 & .119 & .109 & 5 & 0.9554 \\
\hline $208 \mathrm{~B}$ & & .120 & & & & \\
\hline
\end{tabular}


Table 13. --Continued

\begin{tabular}{|c|c|c|c|c|c|c|}
\hline Sample & $\begin{array}{l}\text { Sample } \\
\text { Weight }\end{array}$ & $\mathrm{Abs}_{660}$ & $\overline{\mathrm{Abs}}$ & $\mathrm{K}$ & $\begin{array}{l}\text { Amt. Ext. } \\
\text { Dil. }\end{array}$ & $\begin{array}{l}\text { gm Phytic Acid/ } \\
100 \text { gm }\end{array}$ \\
\hline $345 \mathrm{~A}$ & 0.5028 & .077 & .077 & .113 & 5 & 0.6012 \\
\hline $345 \mathrm{~A}$ & & .077 & & & & \\
\hline 345 B & 0.5001 & .072 & .077 & .113 & 5 & 0.6044 \\
\hline $345 B$ & & .081 & & & & \\
\hline $346 \mathrm{~A}$ & 0.5033 & .100 & .098 & .113 & 5 & 0.7644 \\
\hline $346 \mathrm{~A}$ & & .095 & & & & \\
\hline 346 B & 0.5004 & .095 & .095 & .113 & 5 & .07452 \\
\hline 346 B & & .095 & & & & \\
\hline $543 \mathrm{~A}$ & 0.5022 & .059 & .058 & .113 & 3 & 0.7556 \\
\hline 543 A & & .056 & & & & \\
\hline $543 \mathrm{~B}$ & 0.5043 & .060 & .060 & .113 & 3 & 0.7784 \\
\hline $543 \mathrm{~B}$ & & .059 & & & & \\
\hline $544 \mathrm{~A}$ & 0.5050 & .060 & .062 & .113 & 3 & 0.8032 \\
\hline $544 \mathrm{~A}$ & & .063 & & & & \\
\hline 544 B & 0.5060 & .050 & .052 & .113 & 3 & 0.6724 \\
\hline 544 B & & .053 & & & . & \\
\hline $545 \mathrm{~A}$ & 0.5031 & .105 & .106 & .119 & 5 & 0.7854 \\
\hline $545 \mathrm{~A}$ & & .107 & & & & \\
\hline 545 B & 0.5027 & .075 & .078 & $: 119$ & 5 & 0.6177 \\
\hline 545 B & & .080 & & & & \\
\hline
\end{tabular}


Table 13. --Continued

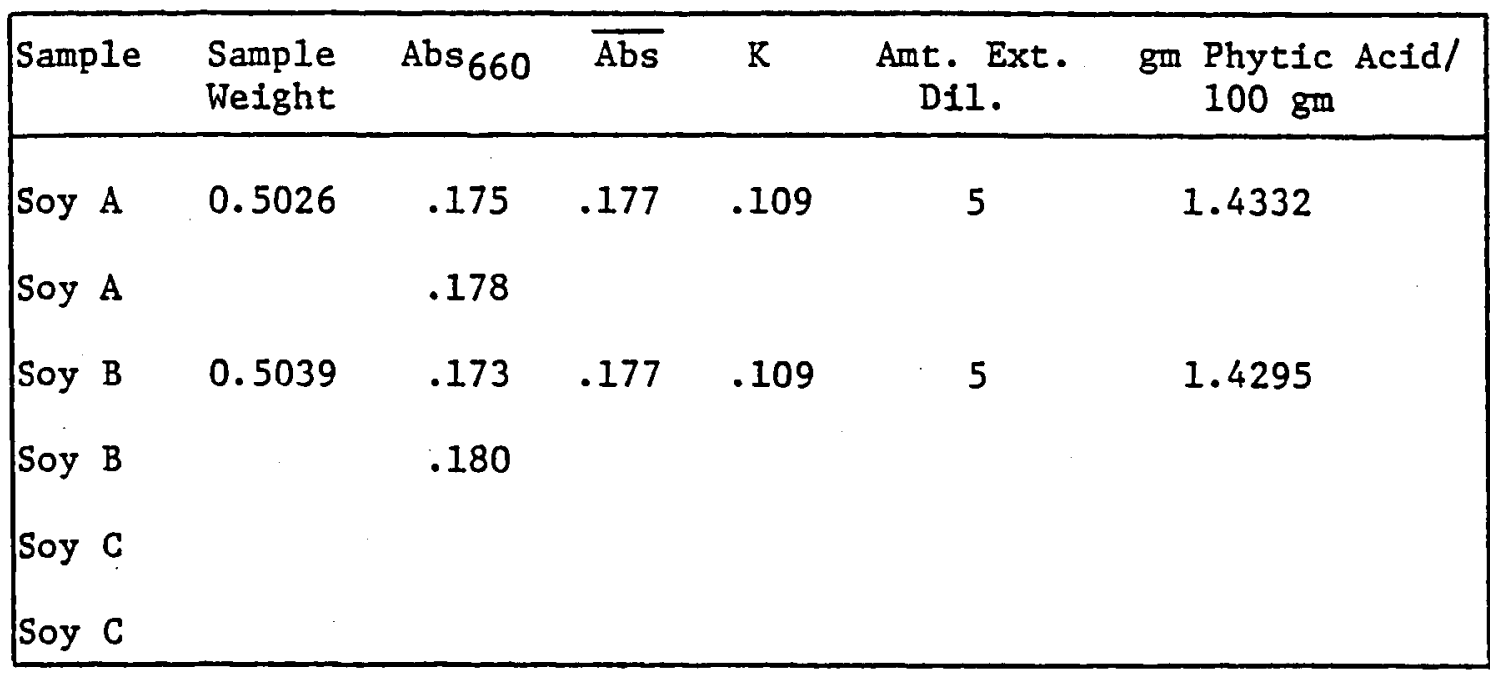

$a_{K}=\frac{\text { Abs }}{\text { microgram } \mathrm{P} / \mathrm{ml}}$

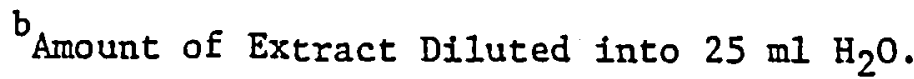


Table 14. Inorganic Phosphorus and Phytic Acid Contents of Samples

\begin{tabular}{|clcc|}
\hline Log. No. & \multicolumn{1}{c}{ Sample } & \% Phosphorus & \% Phytic Acid \\
\hline 161 & Tepary, Tiburon Island, Mexico & 0.12 & 1.02 \\
162 & Domestic White Tepary & 0.15 & 0.71 \\
163 & Domestic Brown Tepary & 0.13 & 0.63 \\
164 & Phaseolus vulgaris, Hermosillo & 0.14 & 0.48 \\
208 & Feather Tree Bean & 0.21 & 0.98 \\
345 & Brown Tepary & 0.09 & 0.60 \\
346 & White Tepary & 0.12 & 0.75 \\
543 & Green Palo Verde & 0.35 & 0.76 \\
544 & Green Palo Verde & 0.24 & 0.74 \\
545 & Green Palo Verde & 0.19 & 0.70 \\
& Soybean & 0.33 & 1.43 \\
\hline
\end{tabular}


CEAPTER 5

CYANOGENIC GLYCOSIDES

\section{Literature Review}

Over 1000 species of plants have been reported to be cyanophoric. The production of hydrocyanic acid, ECN, is attributed to the enzymatic hydrolysis of cyanogenic glycosides-0-Beta-glycosides of alpha-hydroxynitriles. At least twenty, three cyanogenic glycosides have been isolated from higher plants. Cyanogenic glycosides are especially comon to the Gramineae, Leguminosae, and Rosaceae families. Some cyanogenic species consumed by man are: cassava tubers, sorghum seed and Eoliage, white clover foliage, linseed presscake, lima beans, bamboo shoots, and nuts of almond and macademia trees.

Cyanogenic glycosides have been reviewed by Conn (1973, 1979); Seigler (1977), and Oke (1979).

The hydrolysis of linamarin, a cyanogen which occurrs in cassava, Iinen flax, and lima beans, is illustrated here.

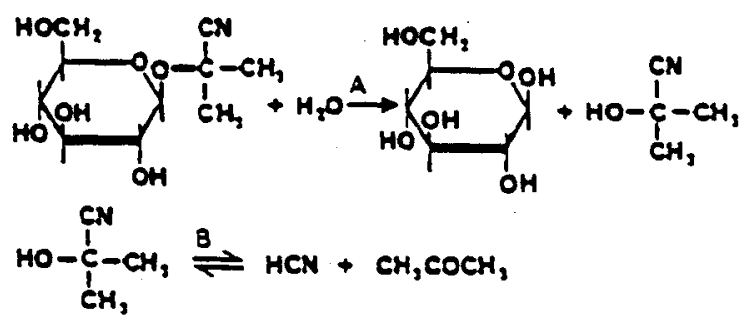


Linamarin if first hydrolyzed by the Beta-glycosidase Iinamarase to form Beta-D-glucophyranose and acetone cyanohydrin. The cyanohydrin then dissociates to HCN and acetone, catalyzed by hydroxynitrile lyase. Hydrolysis of cyanogenic glycosides occurrs only after the tissues of cyanogenic plants are macerated and the glycosides are brought into contact with its catabolic enzymes. This suggests that there is an intercellular or intracellular separation of the enzyme from the glucoside in intact plants.

Studies by Mao and Anderson (1967) suggest that cyanogenic plants may contain glycosidases possessing great specificity for the cyanogenic glycosides found in these plants.

Cyanide as $\mathrm{HCN}$ or $\mathrm{NaCN}$ is rapidly absorbed from the upper digestive tract. Cyanide exerts its toxic effects by complexing with iron in hemoglobin and copper in cytochroma oxidase (Oke, 1969). The blood therefore can't carry, and the oxidase can't react with, $0_{2}$. Aerobic cellular respiration ceases and death ensues from a generalized anoxia. The lethal dose of $\mathrm{HCN}$ for humans is given as $0.5-3.5 \mathrm{mg} / \mathrm{kg}$ oraily in a single dose (Montgomery, 1969). The heart, brain, and nervous system are rapidly affacted; death results in a few minutes if the dose is relatively large.

HCN from cyanogenic glycosides in foods is detoxified to thiocyanate by the enzyme rhodanese, and the thiocyanate is excreted in the urine (Westley, 1973).

$$
\mathrm{CN}^{-}+\mathrm{S}_{2} \mathrm{O}_{3}{ }^{2-} \stackrel{\text { Rhodanese }}{\longrightarrow} \mathrm{SCN}^{-}+\mathrm{SO}_{3}{ }^{2-}
$$

Rhodanese occurrs in several animal tissues, with the highest 
concentrations in the liver. The effectiveness of the process depends on the supply of $\mathrm{Na}_{2} \mathrm{~S}_{2} \mathrm{O}_{3}$. Animal tissues can also catalyze the transfer of the sulfur atom of cysteine to cyanide to form thiocyanate. The immediate sulfur donor is mercaptopyruvate, which is obtained by transamination of cysteine.

Thioncyanate can, in turn, in the presence of hemoglobin as peroxidase catalyst, be oxidized in the erythrocyte to cyanate:

$$
\mathrm{CN}^{-}+\mathrm{H}_{2} \mathrm{O}_{2} \quad \mathrm{OCN}^{-}+\mathrm{H}_{2} \mathrm{O}
$$

(Wilson and Harris, 1960; Oram and Reiter, 1966; Chung and Wood, 1971).

The appearance of the symptoms of cyanide toxicity following ingestion of cyanogenic glycoside containing foods implies that either autolysis of the glycosides has occurred within the food or that the animal has hydrolyzed the glycosides to $\mathrm{HCN}$ and the aglycone. Whether animals have the ability to hydrolyze cyanogenic glycosides in the gastrointestinal tract remains unclear.

Barret et a1. (1977) showed that linamarin administered early to rats is both absorbed and metabolized to yield thiocyanate, which is then excreted in the urine. Nineteen percent of single doses of linamarin administered orally appeared as the intact glycoside in the urine in the first 24 hours. Another $24 \%$ was excreted as urinary thiocynate, but no linamarin was found in the feces. Whether hydrolysis occurred in the digestive tract or thelinarmin was first absorbed and then hydrolyzed by intracellular enzymes was not answered by the experiments. If hydrolysis did occur in the digestive tract, the HCN was absorbed and converted to thiocyanate. Some Iinamarin, apparently, was absorbed 
into the circulatory system of the rat, where it could be acted upon by intracellular Beta-glycosidases. Beta-glycosidases are known to occur in mammalian tissue, but their activity against cyanogenic glycosides isn't known.

Conn (1979) reported on two recent human deaths resulting from ingestion of amygdalin. In both instrances, the symptions of cyanide polsoning occurred within one hour of ingestion. The rapidity with which the symptoms occurred suggested that amygdalin can be absorbed into the circulatory system of man and that sufficient hydrolysis by intracellular enzymes released enough HCN to produce fatalities.

Barret et al. (1978) studied the effects of dietary cyanide on urinary and plasma thiocyanate levels, grwoth, and histology in rats. The rats were fed low protein but otherwise adequate diets for 8 weeks, which contained KCN with levels varying from 0 to 2400 parts per million. An inverse relationship was found between the level of dietary KCN and the weight gain and feed consumption. Histological examination of the brain, spinal cord, duodenum, liver, kidney, spleen, lung, leg muscle, thyroid, and bone marrow showed no differences among the groups. Oke (1979) has discussed the role of cyanogenic glycosides in sickle cell anemia and in the prevenstion of cancer. Palmer et al. (1980) have recently Isolated the two cyanogenic glycosides from linseed oil meal which are responsible for that foodstuff's effectiveness against selenium toxicity.

Seigler (1977) has reviewed methods for the isolation and detection of cyanogenic glycosides from plant materials. ${ }^{13} \mathrm{C}$ NMR 
spectroscopy has recently been used to elucidate the structures of two cyanogenic glycosides, linustatin and neolinustatin from linseed meal (Smith et al., 1980).

Some values of HCN released from various plant tissues are listed below (Conn, 1979):

Plant

Sorghum - Young green leaves

Bitter Almond Seed

Peach Seed

Lima Bean (Puerto Rico, small black)

Lima Bean (American, white)

Cassava Tuber
$\mathrm{HCN}$ Yield (mg/100 gmt 60 290 160 400 10 $7-33$

Lehmann et al. (1979) have measured the amounts of HCN in 24 wheat, rye, maize, and oat types. The HCN contents were found to range between 0.1 and 45 micrograms/100 gm dried mass.

Ades and Mendoza (1979) have determined the HCN contents of 44 varieties of Phaseolus beans commonly consumed in Mexico, including 39 of Phaseolus vulgaris, $1 \underline{P}$. acutifolius, $2 \underline{P}$. cocineus, and $2 \underline{p}$. Iunatus. The only varieties which gave positive varleties were the two varieties of $\underline{\mathrm{P}}$. Iunatus, which liberated 14 and $9 \mathrm{mg} \mathrm{HCN} / 100 \mathrm{gm}$ bean.

\section{Methodology}

The acid titration method of the official AOAC (1975) procedure for the determination of HCN formation by hydrolysis of glycosides in bean was followed. 
Materials

Ferric Alum Indicator, $0.02 \mathrm{~N} \mathrm{AgNO}_{3}$, and $0.02 \mathrm{~N} \mathrm{KSCN}$ solutions were prepared by standard procedures.

\section{Titration Method}

In the procedure hydrocyanic acid, the product of enzymatic autolytic hydrolysis of cyanogenic glycosides, is distilled from a bean slurry into a recelving beaker containing $20 \mathrm{ml}$ of $0.02 \mathrm{~N}_{\mathrm{AgNO}_{3}}$ acidified with nitric acid. Silver cyanide is produced upon contact of the HCN with the silver nitrate solution: the silver cyanide, in the presence of exce.s silver fon, then presumably goes on to form the sparingly soluble silver dicyanoargentate complex.

$$
\begin{aligned}
& \mathrm{Ag}^{+}+2 \mathrm{CN}^{-}=\mathrm{Ag}(\mathrm{CN})_{2}^{-} \\
& \mathrm{Ag}^{+}+\mathrm{Ag}(\mathrm{CN})_{2}^{-}=\mathrm{Ag} \mathrm{Ag}(\mathrm{CN})_{2}
\end{aligned}
$$

When the distillation is finished, the silver dicyanoargentate precipitate is filtered out with a gooch. Ferric alum indicator is then added to the distillate and excess silver nitrate is titrated with $0.02 \mathrm{~N} \mathrm{KSCN}$ to form the white AgSCN precipitate. When the silver ion is exhausted, the potassium thiocyanate reacts with ferric ion to form $\mathrm{Fe}(\mathrm{CNC}){ }_{6}^{3-}$, which is orange in color and marks the endpoint of the titration.

Testing Out of Procedure

To get a demonstration of the procedure, hydrocyanic acid was prepared by the method of Brauer (1952) and the \% yield determined by the acid titration method. $0.0060 \mathrm{gram} \mathrm{FeSO}_{4} \mathrm{H}_{2} \mathrm{O}, 4.0 \mathrm{ml} \mathrm{H}_{2} \mathrm{O}$, and $1.0 \mathrm{ml}$ conc. sulfuric acid were added to a $50 \mathrm{ml}$ round bottom flask. 
The flask was placed in a water bath and attached to a distillation apparatus. The water bath was heated to $90^{\circ} \mathrm{C}$, at which point $10 \mathrm{ml}$ of $0.05 \mathrm{~N} \mathrm{NaCN}$ was added Iropwise through a separatory funnel. The digestion was carried out at $90^{\circ} \mathrm{C}$ for one hour and twenty minutes. The water bath was then removed and replaced by a bunsen burner. Hydrocyanic acid was distilled off into the receiving beaker, containing $25.7 \mathrm{ml} 0.0208 \mathrm{NgNO}_{3}$ acidified with nitric acid, for twenty minutes. The white silver dicyanoargentate precipitate accumulated in the beaker. The distillate was then titrated with $0.02 \mathrm{~N} \mathrm{KSCN}$; the percent yield of HCN was found to be $50 \%$ as expected.

Analysis of Samples

All samples were ground in a Wiley Mill through a number 30 screen (none of the samples were treated or defatted). The analyses were performed in duplicate with the exception of $\log 161$, for which there was only enought sample for a single analysis.

Approximately 20 gram of sample was added to a flat bottomed 1 liter found bottom flask. $100 \mathrm{ml}$ of water was then added and the mixture was macerated for about 5 minutes with a glass stirring rod. The flask was then stoppered and incubated at room temperature with stirring for at least two and one-half hours. After the incubation period, $100 \mathrm{ml}$ more of $\mathrm{H}_{2} \mathrm{O}$ was added to the flask; the flask was then attached to a distillation apparatus. The receiver beaker contained $20 \mathrm{ml} 0.0208 \mathrm{NgNO}_{3}$ acidified with $\mathrm{I} \mathrm{ml}$ conc. $\mathrm{HNO}_{3}$. The AOAC procedure calls for a steam distillation to be performed. Because no steam source was available in the laboratory, a stirrer-hot plate was used. The 
receiver beaker contained $20 \mathrm{ml} 0.0208 \mathrm{~N}_{\mathrm{AgNO}_{3}}$ acidified with $1 \mathrm{ml}$ conc. $\mathrm{HNO}_{3} \cdot$

The samples were heated up to the point just below the temperature at which they would froth over into the distillation head. The distillations were carried on for at least $2 \& 1 / 2$ hours. The receiver beakers were then titrated with $0.02 \mathrm{~N} \mathrm{KSCN}$ standard using $3-4 \mathrm{mI}$ of ferric alum indicator.

Half of the samples could be heated up to the point where the thermometer in the distillation heat would read $96^{\circ} \mathrm{C}$ and significant amounts of water could be distilled over, approximately $50 \mathrm{ml}$. Water from the other samples could not be distilled over to a significant degree because of heavy frothing of the bean slurries. In any case, by allowing the distillations to proceed for at least $2 \& 1 / 2$ hours, it was decided that most of the HCN produced from hydrolysis of cyanogenic glycosides would be distilled over into the receiving beaker.

\section{Results and Discussion}

Cyanide was not detected in any of the bean samples. Cyanide was detected in a lima bean sample (Western Valley Brand Baby Lima) which was run as a control. The cyanide content of the lima beans was determined to be $3.51 \mathrm{mg} \mathrm{HCN} / 100$ gram sample. During the distillation of the lima bean samples, some of the silver ion in the receiver beaker appeared to be reduced to silver metal. Thismay be a source of error in the HCN value of the lima bean. Ades and Mendoza (1979) had previously examined one variety of tepary bean, $\underline{P}$. acutifolius, and detected no HCN. It was not surprising 
then to find no evidence of cyanogenic glycosides in the tepary beans studied here. No reports of cyanogenic glycosides in Lysiloma watsonii and Cercidium microphyllum have appeared in the literature as far as could be ascertained.' The HCN content of the control lima bean was determined to by $3.51 \mathrm{mg} / 100 \mathrm{gm}$, which is in the same order of magnitude as the two Iima beans analyzed by Ades and Mendoza, $9 \& 14 \mathrm{mg} / 100 \mathrm{gm}$. 
CHAPTER 6

\section{SUMMARY OF RESULTS}

Table 15 and 15 are a summary of the contents or activities of the antinutritional factors examined in the bean samples. The temptation now arises to indulge in a little gratuitous speculation and predict which of the legumes should be safe for human consumption. Unfortunately, not enough work has been done in the area of antinutritional factors so that one can predict the physiological or nutritional problems that might arise upon consumption of the beans from knowledge only of the biochemical composition of the legumes. The task is similar to predicting the nutritional quality of a protein solely from data on its amino acid composition.

In the case of the flatulent oligosaccharides, studies have been performed in which the flatus production in human subjects following consumption of bean diets has been measured without knowledge of the Elatulent oligosaccharide content of the bean (Calloway, 1968). Flatus production in human subjects following ingestion of purified raffinose has also been measured (Rackis, 1974). It is not known whether the flatus production from purified flatulent oligosaccharides would equal the flatus production from beans containing the corresponding amounts of those oligosaccharides. It was mentioned previously that beans are suspected of containing another as yet unidentified flatus producing 
component in addition to flatulent oligosaccharides. In view of this fact, it is probable that, given two experimental diets, one consisting of purified oligosaccharides and the other consisting of beans containing the same amounts of oligosaccharides as in the first, the bean diet would effect more flatus production. The biggest obstakle in predicting flatus production from data on raffinose and stachyose contents is that each individual has a different bacterial composition in the gastrointestinal tract (Gall, 1968). Thus, each individual's susceptibility to flatulence varies greatly.

In the case of trypsin inhibitors, although many studies have been carried out to determine the physiological effects of trypsin inhibitors from raw and cooked beans, specific trypsin inhibitor activity in terms of TIU/mg sample has not been correlated with the degree of physiological effect. How much of a bean diet at what level of with animals or humans, is not known. Likewise, in the case of lectins, specific hemagglutinating activity in terms of titer values has not been sufficiently correlated with severity of toxicity effects. As mentioned previously, Jaffe et al. (1972) has classified lectins into four categories, depending on their ability to agglutinate certain blood types. Types $A$ and $C$ were found to be lethal when injected into mice intraperitioneally, while $B$ and $D$ were not. Rats fed diets consisting of raw type $A$ and $C$ beans (with trypsin digested casein) lost weight and died, while those fed $B$ and $D$ showed no signs of toxicity. What concentration of type $A$ or $C$ lectin, as measured in the titer value of 
the lectin extract in a hemagglutination assay with a specific blood type, must be present in the beans fefore toxicity problems arise, was not determined. Determining this information for rats would be a difficult endeavor for rat humans it would be even more so.

In the case of phytic acid, once again, it is known what percent of the diet phytic acid must constitute for mineral deficiencies to occur in test animals. This information is not known for humans.

The conclusion to all of this is that the data determined in this thesis can only serve as a basis for fu:.ther investigations into the potential problems of antinutritional factors in the desert legumes. It cannot be used to conclude whether the legumes are "safe" for human consumption. A logical continuation of this work would be as follows. A bioassay for flatus production, following consumption of the desert beans by human subject, could be performed using the breath analysis method of Calloway (1968). This would be especially appropriate for samples 162, 163, 164, and 346, which have rather high flatulent oligosaccharide contents. Long term feeding studies could be carried out on mice or rats using cooked bean diets to see if the residual trypsin inhibitor of hemagglutination activity after heat treatment results in any otxicity problems. Samples $163,164,345$, and 346 have the highest residueal TI activity after heat treatment. The green Palo Verde beans retained the most hemagglutinating activity after heat treatment. Lastly, feeding studies could be conducted on mice using cooked bean diets to determine if any long term mineral deficiencies arise as a result of the phytic acid levels in the beans, low as they are. 
Table 15. Summary of Antinutritional Factors.

\begin{tabular}{|c|c|c|c|c|c|c|c|c|c|c|c|c|c|}
\hline Sample & $\begin{array}{l}\text { Total Rafflooee } \\
\text { Stachyose Percent }\end{array}$ & $\begin{array}{l}\text { Phytle Ae1d } \\
\text { Percent }\end{array}$ & $\begin{array}{l}\text { TrypeIn } \\
\text { Rav } \\
\text { Sanple }\end{array}$ & $\begin{array}{l}\text { Inhibltor } \\
\text { Heat } \\
\text { Treated }\end{array}$ & $\begin{array}{c}\text { Activity } \\
\text { Inectivetion }\end{array}$ & $\mathrm{si}^{\mathrm{x}}$ & He & inget & liut & $\begin{array}{l}\text { Inat: } \\
\text { leat } \\
\text { ceate } \\
\text { s }\end{array}$ & ion & $\begin{array}{c}\text { Aecay } \\
\text { Reduct10 } \\
\text { R }\end{array}$ & $\begin{array}{r}\text { lon } \\
H\end{array}$ \\
\hline $\begin{array}{c}\text { Topary, Tiburon } \\
\text { tolend, Hexico } \\
161\end{array}$ & 1.15 & 1.02 & 35.1 & 2.5 & 92.9 & 48 & 14 & 36 & - & - & - & 100100 & 100 \\
\hline $\begin{array}{l}\text { Doweet le White } \\
\text { Tapery } \\
162\end{array}$ & 4.89 & 0.71 & 17.4 & 3.4 & 80.5 & 35 & 22 & 36 & 1 & - & 1 & 97100 & $>97$ \\
\hline $\begin{array}{c}\text { Donent 1C Brown } \\
\text { Tepery } \\
163\end{array}$ & 6.43 & 0.63 & 11.9 & 3.7 & 68.9 & 48 & 14 & 21 & 2 & - & 2 & $>96 \quad 100$ & 90 \\
\hline $\begin{array}{l}\text { Phaseolue vulgarle } \\
\text { Hermol110 } \\
164\end{array}$ & 5.29 & 0.48 & 16.6 & 4.1 & 75.3 & 33 & 21 & 36 & 1 & - & 1 & 97100 & $>97$ \\
\hline $\begin{array}{l}\text { Peather Tree } \\
\text { Bean } \\
208\end{array}$ & 2.97 & 0.98 & 60.4 & 1.8 & 97.0 & 9 & 5 & 15 & 1 & - & 2 & 89100 & 87 \\
\hline
\end{tabular}

TIU/as eapple

briv/es oanole

C. Pronece Ireated Rabbit slood

olood

H - Pronae Ireated Haneter slood

Numbers - Titer Valuee 
Table 16. Summary of Antinutritional Factors

\begin{tabular}{|c|c|c|c|c|c|c|c|c|c|c|c|c|c|c|}
\hline Seaple & $\begin{array}{l}\text { Total Raft Inoee } \\
\text { Stachyoce Percent }\end{array}$ & $\begin{array}{l}\text { Phytic Acid } \\
\text { Percent }\end{array}$ & $\begin{array}{l}\text { Trypein } \\
\text { Rew } \\
\text { Sample }\end{array}$ & $\begin{array}{l}\text { Inhibitor } \\
\text { Heat } \\
\text { Treated }\end{array}$ & $\begin{array}{l}\text { Activity } \\
\text { Percent } \\
\text { Inmet Ivetion }\end{array}$ & se & $\begin{array}{l}\text { He: } \\
\text { on } \\
\text { ople }\end{array}$ & mage & & $\begin{array}{l}\text { Inat } \\
\text { Heat } \\
\text { reats }\end{array}$ & Ion & $\begin{array}{l}\text { Aesey } \\
\text { Pet } \\
\text { Redu }\end{array}$ & teent & on \\
\hline Drom Tepary & 3.27 & 0.60 & 18.9 & 3.9 & 79.6 & 33 & 23 & 36 & 1 & - & 4 & 97 & 100 & $>89$ \\
\hline $\begin{array}{l}\text { White Tepary } \\
346\end{array}$ & 4.48 & 0.75 & 15.4 & 4.0 & 74.0 & 22 & 24 & 36 & - & 1. & 2 & 100 & 296 & 294 \\
\hline $\begin{array}{l}\text { Green Palo Verda } \\
\text { S43 }\end{array}$ & 1.66 & 0.76 & 2.3 & 1.6 & 30.4 & 9 & 6 & 15 & 5 & 3 & 6 & 44 & 50 & 60 \\
\hline Green Pelo Verde & 3.55 & 0.74 & 2.6 & 2.8 & 0.0 & 8 & 4 & 16 & 4 & 3 & 6 & so & 25 & 63 \\
\hline $\begin{array}{l}\text { Green Palo Verde } \\
\text { SAS }\end{array}$ & 3.57 & 0.70 & 4.7 & 2.8 & 40.0 & 8 & 3 & 10 & 4 & 4 & 5 & so & 0 & 50 \\
\hline
\end{tabular}

iviv/as ample

biv/mg eanple

$C_{R}$ - Pronace Treated Rabblt slood

D - Pronece o Irypein Treated Bovine Blood

H - Pronace Treated Haneter blood

Numbere - Itter Velues 


\section{APPENDIX A}

\section{CALCULATIONS FOR FLATULENT OLIGOSACCHARIDES}

\section{Sample Calculation}

The percent sucrose, raffinose, and stachyose of sample number 163 are calculated here.

$$
\begin{aligned}
& W=\text { weight of extracted sample }=1.3128 \mathrm{gram} \\
& \mathrm{VS}=\text { total volume of spiked extract }=10.00 \mathrm{ml} \text {. } \\
& \mathrm{VU}=\text { total volume of unspiked extract }=25.00 \mathrm{ml} \text {. } \\
& I=\text { injection volume of extract }=50 \times 10^{-3 \mathrm{ml}} \text {. } \\
& I=\text { amount of raffinose added to spiked sample }=1.74 \mathrm{~cm}^{2} . \\
& \text { SucU }=\text { mean peak area of sucrose in unspiked sample }=1.74 \mathrm{~cm}^{2} \text {. } \\
& \text { SucS }=\text { mean peak area of sucrose in spiked sample }=1.79 \mathrm{~cm}^{2} . \\
& \text { RafU }=\text { mean peak area of raffinose in unspiked sample }=0.28 \mathrm{~cm}^{2} \text {. } \\
& \text { RafS }=\text { mean peak area of raffinose in spiked sample }=4.39 \mathrm{~cm}^{2} \text {. } \\
& \text { StacU }=\text { mean peak area of stahyose in unspiked sample }=1.60 \mathrm{~cm}^{2} \text {. } \\
& \text { StacS }=\text { mean peak area of stachyose in spiked sample }=1.53 \mathrm{~cm}^{2} \text {. }
\end{aligned}
$$

Response Factors from Standard Solution (Figure 2 in Chapter One):

$$
\begin{aligned}
& \text { Sucrose }=7264.53 \mathrm{~cm}^{2} / \mathrm{gram}=\mathrm{RFSu} \\
& \text { Raffinose }=6688.24 \mathrm{~cm}^{2} / \mathrm{gram}=\mathrm{RFRa} \\
& \text { Stachyose }=6896.55 \mathrm{~cm}^{2} / \mathrm{gram}-\text { RFSt }
\end{aligned}
$$


A correction factor (C.F.) is first determined which.corrects for the change in response of the refractive index detector between injection of the standard solution and injection of the sample extract.

C.F. $=\frac{\frac{\text { RafS-RafU }}{\mathrm{vS} \times I}}{\mathrm{RFRa}}=\frac{\frac{(4.39-0.28) \mathrm{cm}^{2}}{0.0759 \mathrm{gm}} \times 50 \times 10^{-3} \mathrm{ml}}{\frac{10.00 \mathrm{ml}}{6688.24 \mathrm{~cm}^{2} / \mathrm{gm}}}=1.62$

Secondly, new response factors for the oligosaccharides are calculated for the sample extract chromatogram.

$$
\begin{aligned}
& \text { Raffinose }=.6688 .24 \mathrm{~cm}^{2} / \mathrm{gm} \times 1.62-10844.33 \mathrm{~cm}^{2} / \mathrm{gm}-\text { New RFRa } \\
& \text { Sucrose }=7264.53 \mathrm{~cm}^{2} / \mathrm{gm} \times 1.62-11778.72 \mathrm{~cm}^{2} / \mathrm{gm}=\text { New RFSu } \\
& \text { Stachyose }=6896.55 \mathrm{~cm}^{2} / \mathrm{gm} \times 1.62=11182.07 \mathrm{~cm}^{2} / \mathrm{gm}=\text { New RFSt }
\end{aligned}
$$

Finally, the oligosaccharide contents of the samples are calculated.

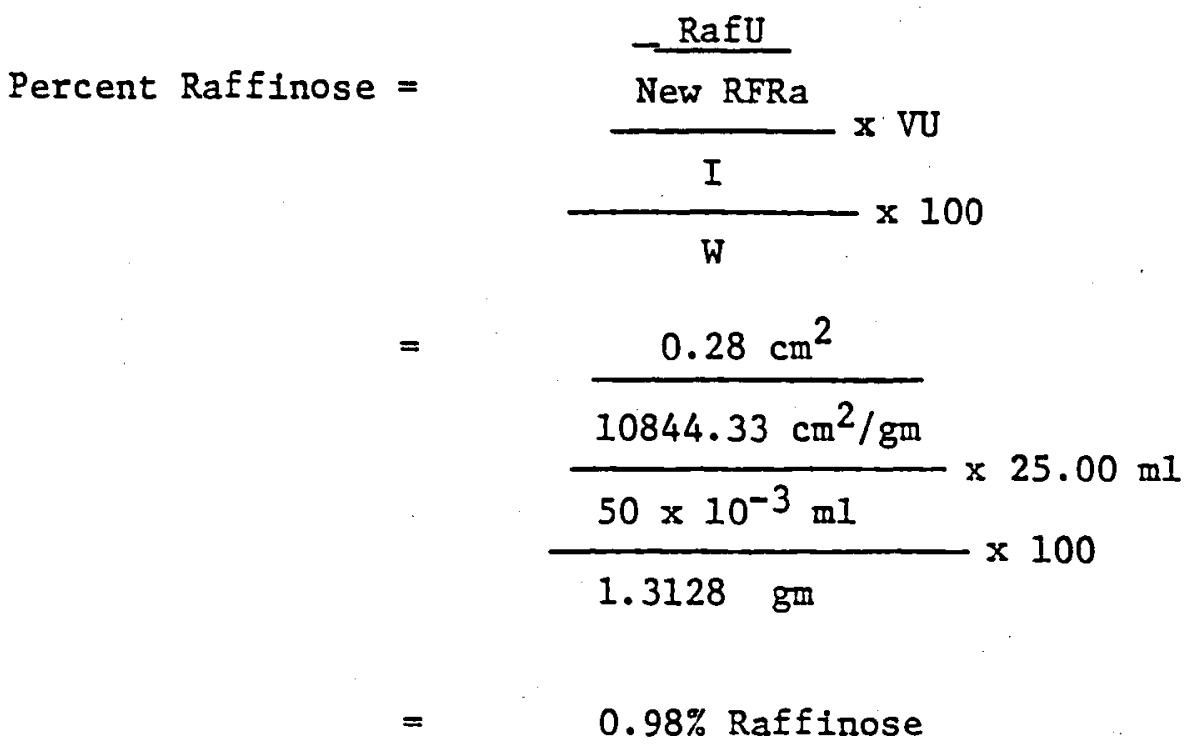


Percent Sucrose $=$

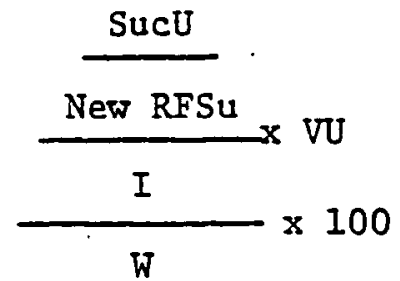

$$
\begin{aligned}
& =\frac{\frac{1.74 \mathrm{~cm}^{2}}{\frac{11778.72 \mathrm{~cm}^{2} / \mathrm{gm}}{50 \times 10^{-3} \mathrm{ml}}} \times 25.00 \mathrm{ml}}{1.3128 \mathrm{gm}} \times 100 \\
& =\quad 5.77 \% \text { Sucrose }
\end{aligned}
$$

Percent Stachyose $=$

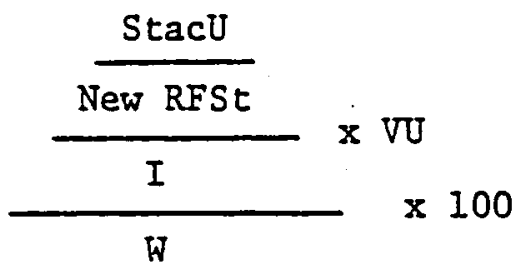

$=$

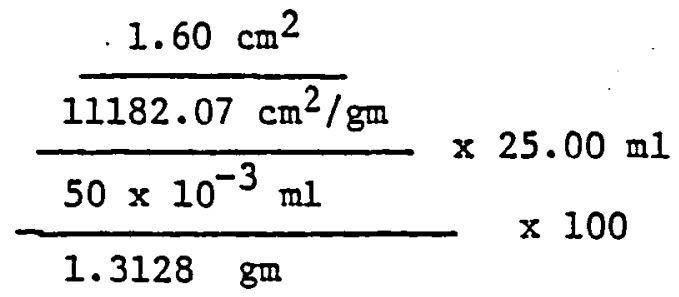




\section{REFERENCES}

Ades, J., and F. Mendoza, Rev. Soc., Quim. Mex., 23 (2), 1979, 90-93.

Allen, K. N., and L. Brilliantine, J. Immunol., 102, 1969, 1295.

Anderson, R. J., J. Biol. Chem., 17, 1914, 141.

Atunes, P. L., and V. C. Sgarbieri, Arch. Latinoam. Nutr., 27 (1), 1977, 33-47.

Atwal, A. S., N. A. M. Eskin, B. E. McDonald, and M. Vaisey-Ginser, Nutr. Reports Internat., 21 (2), 1980, 257-267.

Babakhadzhaeva, S. A., N. U. Rizaev, and A. S. Gorakhavskaya, KhimiloFarmatsevticheskil Zhurnal, 215, 1968.

Barrett, M. D., D. C. Hill, J. C. Alexander, and A. Zitnak, Can. J. Physiol. Pharmacol., 55, 1977, 134.

Barrett, M. D., J. C. Alexander, and D. C. Hill, Nutr. Reports Internat., 18 (4), 1978, 413-419.

Becker, R. A., A. C. Olson, D. R. Frederick, S. Kon, M. R. Gumbmann, and J. R. Wagner, J. Food Sci., 39, 1974, 767.

Berk, J. E., ed., Gastrointestinal Gas, Annals of the New York Academy of Sciences, 150, $1968,1-90$.

Black, I. T., and E. B. Bagley, J. Am. Oil Ch., 55, 1978, 228.

Bond, J. H., R. R. Engel, and M. D. Levitt, J. Exp. Med., 133, 1971, 572.

Booth, A. N., D. J. Robbins, W. E. Ribelin, and F. De Eds., Proc. Soc. Exp. B101. Med., 104, 1960, 681.

Boyd, W. E., and R. M. Reguera, J. Immuno1., 62, 1949, 333.

Brauer, G., Handbuch der praparativen anorganischen Chemie, Enke, Stuttgart, 1952, p. 500 .

Bundy, H. F., N. Kokawsky, and W. Cohen, Arch. Biochem. Biophys., 95, 1961, 271-278. 
Calloway, D. H., D. J. Colasito, and R. D. Mathews, Nature, 212, 1966, 1238.

Calloway, D. H., and E. L. Murphy, Annals of New York Academy of Sciences, 150, 1968, 82-96.

Calloway, D. H., C. A. Hickey, and E. L. Murphy, J. Food Sci., 36, 1971, 251.

Chang, R., S. Schwimmer, and H. K. Burr, J. Food Sci., 42 (4), 1977, 1098-1101.

Chen, L. H., R. R. Thacker, and S. H. Pak, J. Food Sci., 42 (6), 1977, 1666-1668.

Chernick, S. S., S. Lipkovsky, and I. L. Chaikoff, Am. J. Physiol. 155, $1948,33$.

Chung, J., and J. L. Wood, J. Biol. Chem., 246, 1971, 555-560.

Conn, E. E., Cyanogenic Glycosides, in Biochemistry of Nutrition I, International Review of. Biochemistry Vol 27, A. Neuberger and T. H. Jukes, eds., University Part Press, Baltimore, 1979.

Cristofaro, E., F. Mattu, J. L. Wuhrmann, Nutrition Monogram, Sugars in Nutrition, H. L. Sipple, eds., Vanderbilt University, 1972.

Davies, N. T., and H. Reid, Br. J. Nutr., 41, 1979, 579-589.

Davies, N. T. and S. E. Olpin, Br. J. Nutr., 41, 1979, 590-603.

Davies, N. T., Proc. Nutr. Soc., 38, 1979, 121-128.

de Lange, J. D., Proc. Nutr. Soc. S. Africa, 2, 1961, 69.

De Muelenaere, H. J. H., J. Nutr., 82, 1964, 197.

de Rham, 0., and T. Jost, J. Food Sci, 44 (2), 1979, 596-600.

Delente, J. and K. Ladenburg, J. Food Sci., 37, 1972, 372-374.

De Stefanis, J. A., and S. G. Ponte, J. Chromatog., 34, 1968, 116.

Eagle, H., B. W. Agranoff, and E. E. Sne11, J. Biol. Chem., 235, 1960, 1891.

E1-Hag, N., N. F. Haard, and R. E. Morse, J. Food Sc1., 43, 1978, 186-187.

Erdman, J. W., J. Am. 0i1. Chemists' Soc., 56, 1979, 736-741: 
Erlanger, B. F., N. Kokạwsky, and W. Cohen, Arch. Biochem. Biophys., 95, $1961,271-278$.

Filho, J. M., F. M. Lajolo, and D. M. Vizeu, J. Food Sc1., 44, 1979, 1194-1200.

Ford, W. W., Zent. Bakterial Parasitenkd. Abt. I. Ref., 58 (129), 1913.

Ford, J. R., G. C. Mustakas, R. D. Schmutz, J. Am. Oil Chemists' Soc., 55, $1977,371-374$.

Gall, L. S., The Role of Intestinal Flora in Gas Formation, Annals of New York Academy of Scieri:es: 150, 1968, 27-30.

Gertler, A., Y. Birk, and A. Bondi, J. Nutr., 91, 1967, 358.

Ghosh, M., B. K. Bachhawat, and A. Surolia, Biochem. J., 183, 1979, 185-188.

Gitzelmann, R., and S. Auricchio, Pediatrics, 36, 1965, 231.

Green, G. M., R. L. Lyman, Proc. Soc. Exp. Biol. Med., 140, 1972, 291.

Green, G. M., B. A. Olds, G. Mathews, and R. I. Lyman, Proc. Soc. Exp. Biol. Med., 142, 1973, 1162.

Gupta, K., and D. S. Wagle, J. Food Sci., 45, 1980, 394-397.

Haismand, D. R., and D. J. Knight, Biochem. J., 103, 1967, 528.

Hankins, C. N., and L. Shannon, J. Biol. Chem., 253 (21), 1978, 77917797.

Harland, B. F., and D. Oberleas, Cereal Chem., 54 (4), 1977, 827-832.

Hartman, G. H., J. Am. Oil. Chemists' Soc., 56, 1979, 731-735.

Henderson, C. W., Research Assistant, Department of Nutrition and Food Science, University of Arizona, 1980.

Heuber, W., and H. Stadtler, Biochem. Z., 64, 1914, 422.

Hove, E. I., and S. King, N. Z. J. of Agricultural Res., 22, 1979, 41-42.

Howard, J., and L. Shannon, Anal. Biochem., 79, 1977, 234-239.

Hymowitz, T. W., W. M. Walker, F. I. Collins, P. Panczer, Commun. Soil Sci. Plant Anal., 3, 1972, 367.

Jacobbson, K., Scand. J. Clin. Lab. Invest., I (Supp1. 14), 1955, 57-65. 
Jaffe, W. G., Ubber Phytotoxine und Bohnan, Anzneim. Forsch., 10, 1960, 1012.

Jaffe, W. G., O. Brucher, and A. Palozzo, Z. Immun. Forsch. Bd., 142, 1972, 439-447.

Jaffe, W. G., and 0. Brucher, Arch. Latinoam. Nutr., 22, 1972, 267.

Jaffe, W. G., Toxic Proteins and Peptides, in Toxicants Occurring Naturally in Foods, 2nd Ed., National Academy of Sciences, Washington, D. C., 1973.

Kakade, M. L., N. Simons, and I. E. Liener, Cereal Chem., 46, 1969, 518526.

Kakade, M. L., D. E. Hoffa, and I. E. Liener, J. Nutr. 103, 1973, 1172.

Kakade, M. I., J. J. Rackis, J. E. McGhee, and G. Puski, Cereal Chem., 51, $1974,376-382$.

Kawamura, S., Tech. Bull. Fac. Agr. Kagawa University, 18, 1967, 117.

Kim, W. J., C. J. B. Smit, T. 0. M. Nakayama, Lebensm. Wiss. Technol., 6, $1973,201$.

Koepke, J. A., and W. B. Stewart, Proc. Soc. Exp. Biol. Med., 115, 1967, 927.

Kohle, H., and H. Kauss, Anal. Biochem., 103, 1980, 227-229.

Kortt, A. A., Biochim. Biophys Acta, 577, 1979, 371.

Krause, W. G., K. Taeufel, H. Ruttloff, and R. Maune, Ennaehrungsforschung, $13,1968,161$.

Korgdahl, A., and H. Holm, J. Nutr., 109, 1979, 551-558.

Kunitz, M., J. Gen. Physiol., 30, 1947, 291-310.

Landsteiner, K., and H. Raubitschek, Zent. Bakteriol. Parasitenkd. Abt. II Orig., 45, 1908, 660 .

.Lehmann, G., H. D. Zinmeister, N. Erb, and 0. Neunhoeffer, Uber den Blausauregehalt von Getreide und Getreideprodkten, Zeitschrift fur Ernahrungswissenschaft, Band 18, Heft 1, 1979.

Levitt, M. D., and J. H. Bond, Ann. Rev. Med., 31, 1980, 127-137.

Liener, I. E., and M. J. Pallansch, J. Biol. Chem., 197, 1952, 29.

Liener, I. E., Arch. Biochem. Biophys., 54, 1955, 223. 
Liener, I. E., J. Agr. Food Chem., 22 (1), 1974, 17-22.

Liener, I. E., Ann. Rev. Plant. Physiol., 27, 1976, 291-319.

Liener, I. E., Proc. Nutr. Soc., 38, 1979, 109-115.

Liener, I. E., Protease Inhibitors and Lectins, in Biochemistry of Nutrition I, A. Neuberger and T. H. Jukes, eds., International Review of Biochemistry, Vol. 27, University Park Press, Balt., 1979.

Lis, H., and N. Sharon, in Methods in Enzymology, V. Ginsberg, eds., Vol. 28, 1972, 360-368, Academic Press, NY.

Li, E., and S. Kornfeld, Biochim. Biophys. Acta, 469, 1977, 202.

Lolas, G. M., and P. Markakis, J. Food Sci., 42 (4), 1977, 1094.

Lyman, R. L., and S. Lepkovsky, J. Nutr., 2, 1957, 269.

Madar, Z., Br. J. Nutr., 42, 1979, 121.

Mao, C. H., and L. Anderson, Phytochemistry, 6, 1967, 473.

McCance, R. A., and E. M. Widdowson, Biochem. J., 29, 1935, 2694.

McCance, R. A., and E. M. Widdowson, J. Physiol., 101, 1942, 44.

McKibbin, J. M., The Determination of Inositol, Ethanolamine, and Serine in Lipids, in Methods of Biochemical Analysis, Vol. VII, D. Glick, eds., Intersicence, NY, 1959, 111.

Miyoshi, M., Y. Hamaguch1, K. Matsumoto, I. Mizuno, J. Nutr. Sci. Vitaminol., 24, 1978, 195-204.

Montgomery, R. D., in Toxic Constituents of Plant Foodstuffs, I. E. Liener, eds., Academic Press, New York, 1969, p. 143.

Moser, H., D. Schneider, and D. Falke, Biochim. Biophys. Acta, 507, $1978,445$.

Murphy, E. L., 7th Research Conference on Dry Beans, Dec. 2-4, 1964, ARS 14-32.

Murray, J., and N. Stein, Proc. Soc. Exp. Biol. Med., 133, 1970, 86.

Nesheim, M. C., J. D. Garlich, and D. T. Hopkins, J. Nutr. 78, 1962, 89.

Neuberg, C., Biochen. Z., 9, 1908, 557.

Nitsan, Z., and Z. Madar, Br. J. Nutr., 40, 1978, 234-241. 
Nowe11, P., Cancer Res., 20, 1960, 462.

Oberleas, D., M. E. Muhrer, and B. L. O'De11, J. Nutr., 90, 1966, 56.

Oberleas, D., Phytates, in Toxicants Occurring Naturally in Foods, 2nd Ed., National Academy of Sciences, Washington, D. C., 1973.

O'Dell, B. L., and J. E. Savage, Proc. Soc. Exp. Biol. Med,, 103, 1960, 304-306.

Oke, 0. L., Wld, Rev. Nutr. Diet., 11, 1969, 118-147.

Oke, O. L., WId, Rev. Nutr. Diet., vol. 33, 1979.

01son, A. E., Abstracts of Papers of the 177 th ACS/CSJ Chemical Congress, $1979, \ldots 37$.

Omosaiye, O., M. Cheryan, Cereal Chem., 56 (2), 58-62, 1979.

Palmer, I. S., E. O. Olson, A. W. Halverson, R. W. Miller, and C. R. Smith, J. Nutr., 110, 1980, 145.

Pardoe, G. I., G. W. G. Bird, G. Uhlenbruch, I. Sprenger, and M. Heggen, Z. Immun. Forsch., 140, 1970, 374.

Pusztai, A., E. M. W. Clarke, and T. P. King, Proc. Nutr. Soc., 38, 1979, 115-120.

Rackis, J. J., D. J. Sessa, F. R. Steggerda, J. Shimizu, J. Anderson, S. L. Pearl, J. Food. Sci., 35, 1970, 634.

Rackis, J. J., J. Amer. 011 Chem. Soc., 51, 1974.

Rackis, J. J., J. E. McGhee, I. E. Liener, M. L. Kakade, and G. Puski, Cereal Sci., 19 (11), 1974, 513-516.

Rackis, J. J., Oligosaccharides of Food Legumes: Alpha-Galactosidase Activity and the Flatus Problem, in Physiological Effects of Food Carbohydrates, A. Jeanes and J. Hodge, eds., ACS Symposium Series $15,1975$.

Rackis, J. J., Biologically Active Components in Soybeans, in Soybeans: Chemistry and Technology, Vol. 1 Proteins, Rvsd. 2nd Printing,

A. K. Smith and S. J. Circle, eds., AVI Publishing Co., Conn., 1978.

Renkonen, K. O., Ann. Med. Exp. Fenn., 26, 1948, 66.

Reynolds, J. H., Biotechnol. Bioeng., 16, 1974, 135.

Richards, E. A., and F. R. Steggerda, Proc. Soc. Exp. Biol. Med., 122, $1966,573$. 
Richards, E. A., F. R. Steggerda, A. Murata, Gastroenterology, 55, 1968, 502 .

Rockland, L. B., B. L. Gardiner, and D. Peiczarka, J. Food Sci., 34, 1969, 411.

Ruttloff, H., A. Taeufel, W. Krause, H. Haenel, and K. Taeufel', Nahrung, 11, 39,1967 .

Seigler, D. S., The Naturally Occurring Cyanogenic Glycosides, in Progress in Phytochemistry, Vol. 4, I. Reinhold, J. B. Harborne, and T. Swain, eds., Pergamon Press, NY, 1977, 83-120.

Sequeira, R., Ann. Rev. Phytopathol., 16, 1978, 453.

Sever, J. L., J. Immunol. $88,1962,320$.

Sgarbieri, V. C., P. L. Atunes, Arch. Latinoam. Nutr., 27 (1), 1977, 33-47.

Sharon, N., and L. H. Lis, Ann. Rev. Biochem., 42, 1973, 541.

Sharpless, G. R., J. Pearsons, and G. L. Proto, J. Nutr., 17, 1939, 545.

Smith, A. K., and S. J. Circle, eds., Soybeans: Chemistry and Technology, Vol. 1, Proteins, Rvsd. 2dn Printing, AVI Publishing Co., Conn., 1978.

Smith, C. R., D. Weisleder, R. W. Miller, I. S. Palmer, and O. E. Olson, J. Org. Chem., 45, 1980, 507-510.

Sotelo-Lopez, A., M. Hernandez-Infante, and M. E. Arteaga-Cruz, Arch. Invest. Med., 9, 1978, 1-14.

Steggerda, R. F., Gastrointestinal Gas Following Food Consumption, Annals of the New York Academy of Sciences, 150, 1968, 57-66.

Stern, N. J., C. W. Heseltine, H. I. Wang, and F. Konishi, Can. Inst. Food Sci. Technol. J., 10 (3), 1977, 197-200.

Stillmark, H., Arch. Pharmakol. Inst. Dorpat., 3, 1889, 59.

Taeufel, K., W. G. Krause, H. Ruttloff, R. J. Maune, Gesamte Exp. Med. Einsch1. Exp. Chir., 144, 1967, 54.

Talmadge, S. N. and L. K. Kirby, Nutr. Reports Internat., 20 (5), 1979, 729-734.

Taylor, T. G., and J. W. Coleman, Br. J. Nutr., 42, 1979, 113-119. 
Thompson, R. M., and I. E. Liener, Fedn. Proc. Am. Soc. Exp. Biol., 37, $1978,278$.

Thompson, S. A., Research Assistant, Department of Nutrition \& Food Science, University of Arizona, 1980.

Wagner, J. R., J. R. Carson, R. Becker, M. R. Gumbmann, and I. E. Danhoff, J. Nutr., 107, 1977, 680.

Warburg, O., Biochem. Z., 189, 1927, 354.

Westley, J., Advan. Enzymo1., 39, 1973, 327.

Whitaker, J. R., and R. E. Feeney, Enzyme Inhibitors in Foods, in Toxicants Occurring Naturally in Foods, 2nd Ed., National Academy of Sciences, Washington, D. C., 1973, 276-298.

Wilson, I. R., and G. M. Harris, J. Am. Chem. Soc., 82, 1960, 120.

Wilson, I. R. and G. M. Harris, J. Am. Chem. Soc., 83, 1961, 286-289,

Yoshikawa, M., and S. Ogura, Agric. Biol. Chem., 42 (9), 1978, 1753-1759.

Young, L., Biochem. J., 30, 1936, 252. 


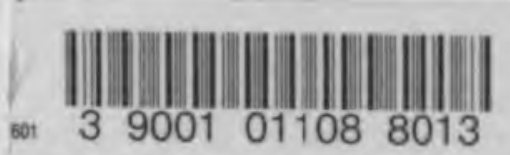

BARCODE HNSHDE 